\title{
Municipal Occupation Taxes in California: The Authority to Levy Taxes and the Burden on Intrastate Commerce ${ }^{\dagger}$
}

\author{
Sho Sato*
}

GTatistics are surely unnecessary to demonstrate the rapid increase $N$ in metropolitan areas with a corresponding increase in governmental entities. ${ }^{1}$ In urban areas the municipal boundaries are not apparent to a casual observer, but business enterprises become critically aware of the number of cities when they discover that their activities are subject to taxes of many cities. Metropolitan areas are fertile breeding grounds for duplicatory and discriminatory taxes by the many taxing entities. Althougl the validity of state and local taxes affecting interstate commerce las been the subject of intensive examination by legal scliolars for many years, ${ }^{2}$ surprisingly scant attention has been paid to problems concerning taxation affecting intrastate commerce. ${ }^{3}$

The purpose of this article is to conduct an inquiry into the area of tax burdens upon intrastate commerce and to determine how this problem has been handled in California.

t The author expresses his appreciation to the Institute of Governmental Studies, Umiversity of Califorma, Berkeley, for a research grant.

* A.B., 1944 Umiversity of Denver, LL.B., 1951 Harvard University; Professor of Law, Umiversity of California.

1 It was recently reported that there were 387 cities in California. CaL. Controuler, Annuai Report of Financial Transactions Concerning Cittes of California xi (Fy 1962-63) [hereinafter cited as CrrIEs: 1962-63]. Although the number of city incorporations since 1920 has not equalled the number incorporated during the two decades preceding 1920 , Crouch, Cartrorama Governasent and Pouttrcs 243 (2d ed. 1960), the increase is still substantial. Since the publication of the Crouch book, when it was reported there were 358 cities, the number has increased to 387 and since the publication of Cahfornia Controller's report four new cities exist. Teleplrone interview with League of California Cities, Sept. 21, 1964. More than one-half of the total number of cities are concentrated in nine counties. Crovcr, op. cit. silpra at 244. In Los Angeles County alone, there are over 70 cities. Cirmes: 1962-63 op. cit. supra at 1-3.

2 For an impressive partial bibhography, see Barrett, State Taxation of Interstate Commerce-"Direct Burdens," "Multiple Burdens," or "What Have Fou?" 4 VAND. L. REv. 496 (1951). For a book devoted to a study of this problem, see HarmaAN, State TAXation of, Interstate Comanerce (1953). For comprehensive studies of more recent vintage, see Hartman, State Taxation of Interstate Commerce: A Survey and an Appraisal, 46 VA. L. REv. 1051 (1960); Developments, Federal Limitations on State Taxation of Interstate Business, 75 HARv. L. REv. 953 (1962).

3 Discussions which have been found are Antieau, Municipal Power to Tax-Its Constitutional Limitations, 8 VAND. L. REv. 698, 740 (1955); French, Municipal Tariffs Under the Guise of Occupation Taxes, 18 Iowa L. REv. 342 (1933); Note, 43 YaLE L.J. 1314 (1934); Note, 5 So. CaL. L. Rev. 164 .(1931). 
The taxes imposed by California local entities are varied. Principally there are (1) the ad valorem property tax, the largest tax revenue producer for the local entities, ${ }^{4}$ (2) the local sales and use tax, the next largest tax revenue source, ${ }^{5}$ and (3) the occupation tax. ${ }^{6}$ The tax burden on intrastate commerce, however, arises primarily from the occupation tax.

The property tax does not present a significant problem in this respect since the taxability of the property by the local entities is governed by the California constitution ${ }^{7}$ and the state statutes. ${ }^{8}$ Although cities have the authority to adopt an assessment date other than the first Monday of $\mathrm{March}^{9}$ the date applicable to all counties, ${ }^{10}$ all cities, even those

4 Authorization for the imposition of ad valorem property tax by counties and cities is found in California Government Code $\$ \S 25202,43000$, respectively. The revenue from property taxes constituted $40.94 \%$ of the total revenue of the counties for the fiscal year 1962-63, Cal. Controlier, annual Report of Financtal Transactions Concerning Counties of CalrFornia vii (FY 1962-63) [hereinafter cited as Countres: 1962-63], and $37.28 \%$ of the total revenue of the cities, CrrIES: 1962-63, op. cit. supra note 1 , at v. The percentage of the property tax to total tax revenue is much higher since counties and cities had substantial revenue from other sources, such as grants from the federal government and the state. For example, the counties derived approximately $92 \%$ of their tax revenues from the property tax.

5 Authorization for the imposition of sales and use tax by counties is found in Cahifornia Revenue and Taxation Code $\S 7201$ and by general law cities in California Government Code $\$ 37101$. The sales and use tax equalled $2.26 \%$ of the total revenue of the counties for the fiscal year 1962-63, Countres: 1962-63, op. cit. supra note 4, at vii, and $18.65 \%$ of the total revenue of cities for the same period, Crries: 1962-63, op. cit. supro note 1 , at v. Again, the percentage of sales and use tax revenue in relationship to total tax revenue is much greater than that indicated above.

6 For a discussion of the authorization to impose an occupation tax, see text commencing from note 25 infra. The percentage of revenue derived from occupation taxes is quite smiall compared to either the property or the sale and use taxes, but the dollar volume amounted to $\$ 38,770,663$ during the fiscal year 1962-63. CrTIEs: 1962-63, op. cit. supra note 1, at 73.

7 See CaL. Const. art. XIII.

8 See CaI. Rev. \& TAX. Code $\S$ 101-5143.

? CaL. Gov't CODE $\S 43122$.

10 Cal. Rev. \& TAX. Code $\S 405$ fixes the first Monday of March as the assessment date for the counties. It is not clear as to whether general law cities may fix a different date. CAL. Gov't CODE $\$ 43002$ fixes the hen date for general law cities as the first Monday of March, but the hen date does not necessarily mean the assessment date. In City of Escondido v. Escondido Lumber, Hay \& Grain Co., 8 Cal. App. 435, 97 Pac. 197 (1908), the court upheld the authority of general law cities to adopt an assessment date different from the state-prescribed "first Monday in Marcb." The statute in question provided: "The Board of Trustees shall have power and it shall be their duty to provide by ordinance a system for the assessment, levy, and collection of all city or town taxes not inconsistent with the provisions of this chapter, which system shall conform as nearly as the circumstances of the case may permit, to the provisions of the laws of this State in reference to the assessment, levy, and collection of State and county taxes, except as to the times for such assessment, levy, and collection, and except as to the officers by whom such duties are to be performed." The statute had also established the first Monday of March as the hen date.

CAL. Gov'T CODE $\$ 43000$ presently provides: "By ordinance the city legislative body shall provide a system for the assessment, levy, and collection of city taxes not inconsistent 
having their own assessment and collection machinery, have adopted that date. ${ }^{11}$ Thus, a single assessment date, plus statutory designation of the situs of many types of property ${ }^{12}$ and decisional rules prohibiting taxation of property with temporary presence ${ }^{\mathbf{1 3}}$ in the taxing entity, have reduced the area of possible intrastate multiple property taxation..$^{14}$ Moreover, a severe burden which might otherwise exist on the transitory property of common carriers or on the unitary property of public utilities by the adoption of different methods of apportionment of value by different taxing entities has been partially forestalled by the central assessment of most of such property by the State Board of Equali-

with this title." Despite the change in the language of the statute considered in City of Escondido, it would seem that its holding is still applicable under the current provision.

It is questionable whether a chartered city needs legislative authority to adopt its own assessment date. Compare West Coast Advertising Co. v. City and County of San Francisco, 14 Cal. 2d 516, 95 P.2d 138 (1939) (levy of revenue taxes is a municipal affair), with CaL. Consr. art. XIII, \& 1 ("All property in the State except as otherwise in this Constitution provided ... shall be taxed in proportion to its value, to be ascertained as provided by law, or as hereinafter provided."). However, such authority is found in California Government Code $\$ 43122$.

11 Cities, both general law and chartered, may make arrangements to have their taxes collected by the county. CAL. Gov'T CODE $\$ \S 43090-101,51500-20,51540-62$. When such arrangements are made, the city must use the assessments made by the county. Car. Gov'r Code $\$ \S 51504,51546$. For the fiscal year 1963-64, all cities except 59 had used the county tax assessment rolls. The 59 cities which conduct their own assessment and collection also use the first Monday of March as the assessment date. Letter From David Jacobson, Associate Statistician, State Board of Equalization, Sept. 30, 1964.

If there were different assessment dates among the cities, property, by changing its situs during the course of the year, might be subjected to a tax by more than one entity. In the interstate arena, items of property may acquire situs in more than one state during the course of a year since goods which have not entered the course of interstate commerce or which have terminated their interstate transportation on the tax date are subject to the property tax regardless of whether the goods will remain in the state for the entire year. Bacon v. Illinois, 227 U.S. 504 (1913). In other words, states are not required to apportion the tax on the basis of days within the state. However, instrumentalities of interstate commerce, such as trains, ships, and airplanes, can be taxed only upon an apportioned basis if they are employed on fixed and regular routes outside the taxing state, or if they are habitually employed in other states. See, e.g., Central R.R. v. Pennsylvania, 370 U.S. 607 (1962); Braniff Airways, Inc. v. Nebraska. Bd. of Equalization, 347 U.S. 590 (1954); Ott v. Mississippi Barge Line Co., 336 U.S. 169 (1949).

12 See, e.g., CAL. Rev. \& TAX. CODE $\S \S 981$ (property on consignment to be assessed where situated), 1016-19 (goods in transit on lien date and controlled and managed by an intrastate water carrier to be assessed in the county where goods were produced or shipped if the taxpayer owns real property there and, if not, his place of domicile), 1137, 1139, 1140, 1141 (designating counties where ferries and vessels may be taxed), 5362 (certain types of aircraft to be taxed in the county where they are habitually situated).

13 See, e.g., Rosasco v. County of Tuolumne, $143 \mathrm{Cal}$. 430, 77 Pac. 148 (1904); Church v. City of Los Angeles, 96 Cal. App. 2d 89, 214 P.2d 550 (1950).

14 The State Board of Equalization has issued guides regarding the situs of property, although, with the exception of contractor's equipment, the handbook merely reiterates the statutory provisions and decisional law. State Bd. of Equalization, Assessor's HaNdBoor AH 021-1 (1950). 
zation. ${ }^{15}$ The State Board apportions the assessed value of the unitary enterprise to the local entities which then levy their $\operatorname{tax}^{16}$ For these reasons, the property tax is not treated here.

Similarly, the sales and use tax does not present a serious problem today. Because the Bradley-Burns Uniform Local Sales and Use Tax $\mathrm{Law}^{17}$ has been widely adopted, ${ }^{18}$ the sale or use of tangible personal property. is not apt to be subjected to either the sales tax or the use tax by more than one taxing entity. ${ }^{19}$ The statute has assigned the sale to the place of business of the retailer, ${ }^{20}$ and a sale which has been taxed under the Uniform Local Sales and Use Tax Law is exempt from the use $\operatorname{tax}$ in another entity. ${ }^{21}$

The net income tax has rarely been utilized by the local entities in California $;^{22}$ thus the danger of multiple burden arising from this form of taxation does not exist.

The occupation tax, then, remains as the principal problem inasmuch as varying forms of this tax have been used as a revenue source by practically every city in the state. ${ }^{23}$ This article will imitially examine the authority of local entities to impose an occupation tax. Next, the general limitations upon such authority will be discussed. ${ }^{24}$ Finally, attention will be focused upon the burdens cast on intrastate commerce by the occupation taxes.

15 CAx. Const. art XIII, \& 14 requires the State Board of Equalization to assess pipe lines, flumes, canals, ditches and aqueducts not entirely within the limits of any one county and all property, other than franchises, of most public utilities, transportation and communication enterprises. Airlines, however, are not covered.

16 For a description of intrastate apportionment of state-assessed property to local units, see 'Jornt Interna Comar. on Assessament Practices, final Report to the CaliFORNIA LEGISLATURE 211 (1959).

17 CAL: REv. \& TAX. CODE $\$ \$ 7200-09$. This law, however, presents the problem whether local entities adopting the provisions thereof are precluded from enacting other consumption taxes on a retail sale.

18 "A local 1-percent sales tax is administered by the State for all 58 counties and all but one of its 384 cities." Cartr. State Bd. of Equalizatton, Anvoat Report 22 (1962-63).

19 Before the City and County of San Francisco came within the Bradley-Burns Uniform Local Sales and Use Tax Law, a purchaser of tangible personal property in San Francisco faced a possibility of paying a purchaser's tax in San Francisco and a use tax in another city.

20 Cat. REv. \& Tax. CODE $\$ 7205$.

21 CAI. Rev. \& Tax. Code $\$ \S 7202(\mathrm{~h})(5), 7203(3)$.

$22 \mathrm{It}$. was reported in 1957 that one city had measured the license tax by net income. League of Caltrornia Cities, Business license Taxes 20, 25 (1957).

23 Every city except three levied occupation taxes according to a report in 1957. Id at 1.

24 The validity of license taxes as applied to specific businesses, such as banks or insurance companies, will not be discussed. For a discussion of these problems, see LeAGUE of Caltrornia Crries, op. cit. supra note 22, at 18-19. 
I

AUTHORITY TO IMPOSE AN OCCUPATION TAX

\section{A. County}

A county, a political subdivision of the state, must find its authority either in a constitutional grant or in a statutory delegation from the state. ${ }^{25}$ If the constitution grants authority to a county to impose an occupation tax, there is no need to seek statutory authority. Therefore, an analysis of the constitution will be undertaken first.

Pertinent to this inquiry are several provisions. Article XI, section 11, of the California constitution provides:

Any county, city, town or township may make and enforce within its limits all such local, police, sanitary and other regulations as are not in conflict with general laws.

Article $\mathrm{XI}$, section 12 reads:

Except as otherwise provided in this Constitution, the Legislature slall have no power to impose taxes upon counties, cities, towns or other public or municipal corporations, or upon the inhabitants of property thereof, for county, city, town, or other municipal purposes, but may, by general laws, vest in the corporate authorities thereof the power to assess and collect taxes for such purposes.

Article XI, section 11, states that a county may enact "local" and "other regulations" which are not in conflict with general laws. An occupation tax measure would arguably fall within the meaning of "local" regulation, and if not, within "other regulations." The cases relating to this question are extremely difficult to assay. For example, Ex parte $W_{\text {olters }}^{28}$ sustained county hicensing of retail hiquor business on the authority of article XI, section 11. There are, however, ambiguities. First, the principal opinion did not discuss whether the license was for a regulatory or revenue purpose, or both; the concurring opinion, however, regarded the hicense as a revenue measure. Second, at times relevant to the case the legislature might already have given to the county authority to adopt an occupation tax. In Ex parte Mount, ${ }^{27}$ the court alluded to article XI, section 11, to sustain a license tax but the issue appears to have been whether the licensing procedure could be employed to enforce the tax. Later, in Merced County v. Helm, ${ }^{28}$ the court, holding that the tax in question was not authorized by the legislature, stated that article XI, section 11, was not a direct grant of authority for a revenue

25 See, e.g., County of Sacramento v. Chambers, 33 Cal. App. 142, 164 Pac. 613 (1917).

2865 Cal. 269, 3 Pac. 894 (1884).

2766 Cal. 448, 6 Pac. 78 (1885).

28102 Cal. 159, 36 Pac. 399 (1894). 
measure enforceable by civil suit only. Whether the court would have characterized a revenue ordinance as a police measure had criminal penalties been attached is left uncertain. If the decision in Helm was obscure, the court left no doubt in Von Schmidt $v$. Widber, ${ }^{20}$ decided in the same year as Helm, that the regulations authorized by article XI, section 11, are "rules of conduct to be observed by the citizens." It seems clear that the court was referring to regulatory police powers. Seven years after Von Schmidt, however, the court in County of Los Angeles v. Eikenberry ${ }^{30}$ held that a revenue measure which permitted the collection of the tax by a civil suit was authorized under the constitutional provision in question. But later in the same year, Ex parte Pfirmann ${ }^{31}$ held that the county could not impose a license for revenue purposes since the legislature had taken away such power. No discussion of article XI, section 11, as a direct grant of power is found in Pfirmann. Because of this omission, one can only speculate as to whether the court assumed that section 11 does not constitute an independent source of revenue power or that, even if it does, the county revenue license ordinance was in conflict with the general laws and therefore invalid. ${ }^{32}$

Since Ex parte Pfirmann, there have been many conflicting cases dealing with ordinances other than revenue measures. Professor Peppin, who analyzed these cases in 1944, came to the following conclusion:

To summarize, then, the power vested in cities and counties by section 11 of Article XI to make and enforce "all such local, police, samitary and other regulations" has been limited to a power to make "police regulations" and this, in turn, has been limited to power to enact penal ordinances. ${ }^{33}$

But the cases are by no means as conclusive as Professor Peppin would have wished. ${ }^{34}$ The most persuasive argument against a broad reading of section 11 is that broadly read, it would constitute a charter, limited only by general law, permitting the entities to do whatever they thought

20105 . Cal. 151, 38 Pac. 682. (1894).

30131 Cal. 461, 63 Pac. 766 (1901).

31134 Cal. 143, 66 Pac. 205 (1901).

$32 \mathrm{~A}$ principle has developed that a general law which merely prohibits county action cannot be' a "general law" within the meaning of article XI, section 11. Ex parte Daniels, $183 \mathrm{Cal}$. 636, 192 Pac. 442 (1920). The impact of this doctrine appears to be considerably weakened in the light of recent cases which have readily found that the legislature has "occupied the field," leaving no room for local regulation. E.g., In re Koehne, 59 Cal. 2d 646, 381 P.2d 633, 30 Cal. Rptr. 809 (1963); In re Lane, 58 Cal. 2d 99, 372 P.2d 897, 22 Cal. Rptr. 857 (1962). But for a recent reversal of this trend, see In re Hubbard, 62 A.C. 116, 396 P.2d 809, 41 Cal. Rptr. 393 (1964).

33 Peppin, Municipal Home Rule in Califorria III: Section 11 of Article XI of the California Constitution, 32 CALIF. L. REv. 341, 368 (1944).

34 Professor Peppin commences his article by conceding that the point is not very clear. Id. at 346. See also the cases pointing to a contrary conclusion. $I d$. at 357 n.59. 
was desirable for the welfare of their inhabitants. ${ }^{35}$ Since Professor Peppin's pronouncement, however, dissenting voices are still heard. ${ }^{\mathbf{3 6}}$

Whatever may be the proper scope of article XI, section 11, with respect to powers other than taxation, article XI, section 12 , appears to deny taxing power to the entities enumerated therein unless that power is granted by the legislature. This implication from article XI, section 12, seems clear, but this section has also had an uncertain history. Although there were earlier intimations that section 12 gave authority to the local entities to impose a $\operatorname{tax}^{37}$ later cases seem to make clear that such is not the rule and that only the legislature has the power to direct the type of taxes which local entities can impose. ${ }^{38}$ In conclusion, it is extremely dubious that either section 11 or section 12 provide the authority to levy an occupation tax.

While an analysis of article XI, sections 11 and 12, suffices for a determination of constitutional grant of taxing power to the general law counties, further complications arise with respect to chartered counties. In 1911 the constitution was amended to provide a degree of "home rule" to the counties by permitting them to adopt a charter. Article XI, section $71 / 2$, subdivision 4 , requires a charter to provide:

For the powers and duties of boards of supervisors and all other county officers, for their removal and for the consolidation and segregation of county officers, and for the manner of filling all vacancies occurring therein; provided, that the provisions of such charters relating to the powers and duties of boards of supervisors and all other county officers shall be subject to and controlled by general laws.

If the above clause can be interpreted as dealing generally with county powers, a county can assume the power to impose an occupation tax by so providing in its charter.

The history of section $71 / 2$ is imconclusive. The primary concern of the proponents of section $7 \mathrm{x} / 2$ was the intermeddling of the legislature in individual county affairs. ${ }^{39}$ The proponents argued that the "political plums" and "sinecures" would be ehminated by placing decision-making

35 Id at $345-46$.

36 See De Aryan v. Butler, 119 Cal. App. 2d 674, 260 P.2d 98 (1953), cert. denied, 347 U.S. 1012 (1954); 28 Ops. CAL. AtT'y GEN. 282 (1956).

37 Ex parte Wolters, $65 \mathrm{Cal} .269,3$ Pac. 894 (1884) (concurring opinion); see Ex parte Mount, $66 \mathrm{Cal}$. 448, 6 Pac. 78 (1885) (erroneously quoting the principal opinion in Ex parte Wolters).

38 Ex parte Pfirmann, 134 Cal. 143, 66 Pac. 205 (1901); Hughes v. Ewing, 93 Cal. 414, 28 Pac. 1067 (1892).

39 See Proposed Amendments to the Constitution of the State of California, wite Legtstattye Reasons for and Agatnst adoption Thereof, Senate Const. Amend. No. 5 (1911). 
in the hands of the people of the county. ${ }^{40}$ It appears that the aim was local determination of local organization. From this, it might be inferred that the purpose of subdivision 4 was merely to permit a county, by adopting a charter, to assign the powers and duties, given to the county from other sources, among the county officers-not to grant an independent source of power to the counties. But there exists a cryptic statement that the amendment was drafted to follow the "safe and tried path pursued in the 'City Home Rule' movement."11 And by 1911 a city, by adopting a charter, was able to provide for powers relating to its "municipal affairs"-which included the power to levy an occupation taxirrespective of any legislative grant of authority. ${ }^{42}$

The various provisions of section $71 / 2$, however, militate against a construction which would make subdivision 4 an independent source of county power. The other required charter provisions relate wholly to matters of internal organization; this is also true of other matters mentioned in subdivision 4. In addition, the provision which granted an independent source of power to cities with respect to their "municipal affairs" speaks clearly of entity powers; ${ }^{43}$ by contrast, subdivision 4 is written in terms of powers and duties of the county officers. If the clause in question was intended to equate county "home rule" with that of a chartered city, a more awkward and ambignous method could not have been conceived. Restricting subdivision 4 to internal organization, however, requires that the proviso clause be reconciled since the constitutional amendment permitting a county to adopt its own charter would appear at the minimum to have left to the county for its own determination the internal allocation of functions among the county officers. To preserve an internal harmony, the proviso clause of subdivision 4 should be interpreted to mean that the allocation of functions must be within the confines of the powers and duties assigned to the county by the general law. ${ }^{44}$ Thus, it must be concluded that a county, by adopting a charter, cannot assume the taxing power.

40 Ibid.

41 Ibid.

42 E.g., Ex parte Braun, 141 Cal. 204, 74 Pac. 780 (1903). The "municipal affairs" exception in article XI, $\$ 6$, of the California constitution was adopted in 1896. A recent dictum has further clouded the picture. There appears in In re Hubbard, 62 A.C. 116, 124, 396 P.2d 809, 814, 41 Cal. Rptr. 393, 398 (1964), the following statenient: "The exclusive right of a chartered city or county to regulate turns on whether or not the subject nuatter is a municipal affair." The court seems to state that a chartered county "home rule" is coextensive to that of a chartered city, but the court cites no authority for this proposition and indulges in no analysis of the difference in constitutional provisions applicable to counties and cities. The term "nuumicipal affairs" appears nowhere in the constitution with respect to the counties.

43 CAL. Const. art. XI, $\$ 6$, as amended in 1896.

44 In Wilkinson v. Lund, 102 Cal. App. 767, 283 Pac. 385 (1929), it was held that a 
At any rate, there presently exists a statute which has been construed to withdraw from the county the power to levy an occupation tax..$^{45}$ No one suggests, even today, that insofar as its power is concerned, a county is not subject to the general laws except for those powers specifically derived from the constitution. ${ }^{46}$

The mentioned statute which expressly denies the counties the power to require a general revenue license ${ }^{47}$ contains an exception: A county may license for revenue purposes "individuals acting as hawkers, itinerant peddlers or itinerant vendors, other than merchants having a fixed place of business in the county, their employees, and farmers selling farm products produced by them." "48 This power does not extend, liowever, to licensing for revenue purposes "any commercial traveler whose business is limited to goods, wares and merchandise sold or dealt in at wholesale in this State." ${ }^{\prime 99}$ Another broad exception to the prohibition against revenue license measures is the authority granted under the Bradley-Burns Uniform Local Sales and Use Tax Law. ${ }^{50}$ With these two exceptions,

chartered county could not place an ad valorem property tax limitation which would prevent it from raising sufficient revenues to carry out the functions delegated by the legislature. The court gave full effect to the proviso of subdivision 4 and reasoned that the constitution was explicit in providing that the charter provisions dealing with powers and duties of the board of supervisors shall be subject to and controlled by the general laws. Reuter v. Board of Supervisors, 220 Cal. 314, 30 P.2d 417 (1934), expressly disapproved the language of Wilkinson, supra, regarding subdivision 4 and, in effect, read the proviso out of the constitution. But the issue before the court was an allocation of functions among the county officers. Accord, Lesem v. Getty, 23 Cal. App. 2d 57, 72 P.2d 183 (1937).

Curphey v. Superior Court, 169 Cal. App. 2d 261, 337 P.2d 169 (1959), gives full effect to the "ratification of the charter" clause in article XI, \& $7 \frac{\mathrm{I}}{2}$, of the California constitution which provides that the charter supersedes "all laws inconsistent with such charter relative to the matters provided in such charter." But again, this case dealt with internal administration.

45 CaI. Bus. \& Prof. Code § 16100.

46 The precise holding of Wilkinson v. Lund, 102 Cal. App. 767, 283 Pac. 385 (1929), has not been rejected. See also Ex parte Pfirmann, 134 Cal. 143, 66 Pac. 205 (1901). It should be noted, however, that the following statement appears in $I n$ re Gritton, 46 Cal. 2d 856, 858, 300 P.2d 7, 8 (1956): "It is not disputed that section 12 of article XI of the Constitution and section 16100 of the Business and Professions Code probibit a noncharter county such as Riverside County from requiring the purchase of a business license for the purpose of raising revenue." One might, at his peril, interpret the above statement to mean that chartered counties are unaffected by the general laws with respect to revenue matters.

47 Cal. Bus. \& Pror. Code $\$ 16100$. The counties at one time were authorized to impose revenue licenses. See, e.g., Cal. Stats. 1883 , ch. $74, \S 25(27)$, at 308, but the authority was withdrawn under Cal. Stats, 1901, ch. 209, § 1, at 635 . See Ex parte Pfirrmann, supra note 46 , construing the statute of 1901.

48 CaL. Bus. \& Prof. Code $\$ 16101$.

48 CaL. Bus. \& Prof. CODe $\S 16103$.

50 CAL. REv. \& TAX. Code $\$ \$ 7200-09$. The rate of county tax under the Uniform Local Sales and Use Tax Law is $1 \%$; CAL. REv. \& TAX. CODE $\$ 7202$ (a), but the taxpayer is entitled to a credit to the extent he pays a city tax under the Uniform Local Sales and Use Tax Law. Cax. Rev. \& TaX. Code $\$ 7202$ (h). 
however, a county appears to be without power to impose an occupation tax.

\section{B. City}

The cities, like the counties, must find their authority to impose an occupation tax in the constitution or a statute. Article XI, sections 11 and 12, of the California constitution, discussed above in connection with a county, ${ }^{51}$ is equally applicable to a city.

But a distinction must be drawn between the general law cities and chartered cities. The chartered cities, by the adoption of a charter under the constitution, ${ }^{52}$ have the power to "make and enforce all laws and regulations in respect to municipal affairs," and "municipal affairs" are not subject to the general laws." At an early date, inatters of finance were deemed to be "municipal affairs" so that chartered cities have constitutional authority to enact occupation tax measures. ${ }^{65}$

The general law cities, however, must look to the general law. Statutory authority is found in section 37101 of the Government Code which provides: "The legislative body may license, for revenue and regulation, and fix the license tax upon, every kind of lawful business transacted im the city, including slows, exhibitions, and games."56 Thus, the general law cities and the chartered cities have the power to levy occupation taxes, although the sources of their authority differ.

\section{II}

IIMITATIONS ON THE POWER TO IMPOSE AIN OCCUPATION TAX

\section{A. Conflict with General Lawes}

Although the authority of the cities to levy an occupation tax is clear, the cities have encountered some difficulty in levying a license tax upon persons regulated by the state. At one time regulatory licensing by the state did not preclude the cities from requiring froin a state licensee a municipal license for revenue purposes. ${ }^{57}$ The court had con-

51 See text accompanying note 25 supra.

62 CAL. CONST. art. XI, \& 8.

I3 Ibid.

54 CAI. Const. art. XI, $\$ 6$.

55 Ex parte Braun, 141 Cal. 204, 74 Pac. 780 (1903). Trebilcox v. City of Sacramento, 91 Cal. App. 257, 266 Pac. 1015 (1928); more recently reaffirmed in Ainsworth v. Bryant, 34 Cal. 2d 465, 211 P.2d 465 (1949); West Coast Advertising Co. v. City and County of San Francisco, 14 Cal. 2d 516, 95 P.2d 138 (1939).

58 It should be noted that a contrary provision appears in California Business and Professions Code $\$ 16000$. See Ex parte Pfirmann, 134 Cal. 143, 66 Pac. 205 (1901) for a construction of that section. However, in light of California Business and Professions Code $\S 16003$, which provides that any act vesting revenue licensing power in the cities supersedes the probibition, the apparent conflict is removed.

57 In re Galusha, 184 Cal. 697, 699, 195 Pac. 406, 407 (1921), explained this rule as 
sistently rejected the argument that a municipal license tax conflicted with the general law which regulated the business.

An interesting doctrine was later to develop and one might start with Horwith v. City of Fresno, ${ }^{58}$ decided in 1946, to trace the evolution. Horwith involved municipal licensing of electrical contractors who were already licensed by the state after passing a state examination given to determine their qualifications. The city required the state licensee to pass a city examination before a municipal license could be obtained. A fee was also required. There was no doubt that the municipal requirement was regulatory in effect rather than a mere revenue measure. In answer to the contentions of the city, which was chartered, the court held that (1) regulatory licensing of electrical contractors was a matter of statewide concern, rejecting the notion that it was a "municipal affair,"50 and (2) the fact that the controls imposed by the city were more stringent than the state requirements did not save the municipal license since the state had occupied the field.$^{60}$ In the course of the opmion the court reasoned: "The state license implies permission to the hicensee to conduct his business at any place within the state. This permission should not be circumscribed by local authorities." context, was to take on unsuspected significance in later cases.

The next case of importance is City and County of San Francisco $v$.

follows: "The municipality, in imposing an occupational tax upon attorneys, is not interfering with state regulations, for it is not attempting to prescribe qualifications for attorneys different from or additional to those prescribed by the state. ... The tax is levied upon the business of practicing law, rather than upon a person because he is an attorney at law. ... A license to practice does not carry with it exemption from taxation." This conclusion was reached even though a violation of the mumicipal revenue license tax was enforceable by criminal prosecution. Ibid. For further discussion of the significance of criminal prosecution, see text accompanying note 72 infra.

5874 Cal. App. 2d 443, 168 P.2d 767 (1946).

50 Classifying a subject matter as a "municipal affair" leaves it a matter for local determination free from any general law. Raisch v. Myers, 27 Cal. 2d 773, 167 P.2d 198 (1946); City of San Mateo v. Railroad Comm'n, 9 Cal. 2d 1, 68 P.2d 713 (1937); City of Pasadena v. Charleville, 215 Cal. 384, 10 P.2d 745 (1932); see Note, 53 Calif. I. Rev. 902 (1965).

60 The supersession of state regulatory laws over municipal regulations is an issue under CAL. Consr. art. XI, \& 11. At the time of this decision, it was generally thouglit that the state had not "occupied the field" in the absence of legislative expression to that effect. See Peppin, Municipal Home Rule in California III: Section 11 of Article XI of the California Constitution, 32 CALIF. L. REv. 341, 388-90 (1944). Therefore local regulations more stringent than state laws were valid. Peppin, supra at 383. But the law was drastically changed, In re Lane, 58 Cal. 2d 99, 372 P.2d 897, 22 Cal. Rptr. 857 (1962), although an earlier erosion is found in Abbott v. City of Los Angeles, 53 Cal. 2d 674, 349 P.2d 974, 3 Cal. Rptr. 158 (1960). But see In re Hubbard, 62 A.C. 116, 396 P.2d 809, 41 Cal. Rptr. 393 (1964). For a discussion of Hubbard, see Note, 53 CarIF. L. REv. 902 (1955).

6174 Cal. App. 2d at 448-49, 168 P.2d at 770. 
Boss, ${ }^{62}$ decided in 1948. A municipal regulatory license, in contrast to a revenue measure, was again involved. Unlike Horwith there was no municipal examination, but the applicant was required to submit data to the city. The city reserved the right to revoke the license if the licensee was determined to be dishonest or guilty of violating any regulation of the state or city. Following Horwith, the court held that the state lad occupied the field and also that the municipal license conflicted with the general law because the city could revoke the license regardless of the action of the state.

In Agnew v. City of Los Angeles, ${ }^{63}$ decided in 1952, the city required a state-licensed electrical contractor to obtain a certificate of registration, pay a fee of 100 dollars, and furnish a bond as conditions precedent to engaging $m$ business in the city. Under the licensing scheme, the city passed upon his qualifications and had the right to refuse or revoke the certificate for specified reasons. Although this scheme would seem to fall squarely within the condemnation of the prior cases, the court found the offensive features to be the fee and the bond. According to the court, the features would nullify the permission given a contractor by the general law to conduct his busimess any place in the state. The court reasoned that if one city can impose such conditions, other cities can do hikewise, and the contractor could be subjected to a prohibitory burden. Thus, Agnew apparently departed front the earlier grounds, which were based on duplicity of regulation, to a rationale more reminiscent of federal cases dealing with multi-state burdens. ${ }^{84}$

Agnew v. City of Culver City, ${ }^{65}$ decided in 1956, represents a clearer departure from the previous cases. The municipal ordinance appears to have had no regulatory feature; insofar as qualification to do business was concerned, it nuerely required the payment of a fee and the securing of a permit. A violation of the ordinance was enforceable by criminal process. The court, based on these features alone, invalidated the ordinance. While the bonding requirement involved in Agnew v. City of Los Angeles $^{66}$ can arguably be classified as regulatory, the fee and the permit in Agnew v. City of Culver City appear to lave been nothing nore than the traditional license tax for revenue. If Agnew v. City of Los Angeles hinted at nultiple burdens, Agnew v. City of Culver City ecloed the principle that no state can tax the privilege of engaging in interstate commerce. ${ }^{67}$

63110 Cal. App. 2d 612, 243 P.2d 73 (1952). See also Lynch v. City of Los Angeles, 114 Cal. App. 2d 115, 249 P.2d 856 (1952).

04 See, e.g., Nippert v. City of Richmond, 327 U.S. 416 (1946).

65 147 Cal. App. 2d 144, 304 P.2d 788 (1956).

${ }^{66}$ See note 63 supra.

67 Compare Spector Motor Serv., Inc. v. O'Connor, 340 U.S. 602, 609 (1951): "This 
In 1958, the California Supreme Court gave its opinion on the problem. In Agnew v. City of Los Angeles, ${ }^{68}$ in a very confusing opinion, the court invalidated the municipal licensing ordinance after comparing the ordinance with the state statute to indicate the areas of overlap. But the comparison leaves much to be desired. The first area of overlap was that the mumcipal ordinance required a permit from the Department of Building and Safety before a person could install wiring while the state law required a hicense before a person could act as a contractor. But the ordinance appears to have required a permit to insure that the proposed work met the municipal safety requirements rather than to insure the qualification of the contractor. In the absence of a state building code or its like, it is difficult to see how the permit in question conflicted with the state law. ${ }^{69}$ The second area of duplication was similar to the first; the contractor had to submit plans for the proposed work and other necessary information, while the state statute provided for investigation and examination of the contractor. Again the court confused the qualification of the applicant with the regulation of the specific work to be performed. The third area of conflict, according to the court, was the municipal requirement of registering and supplying certain information concerning his business, state hicense, and municipal license tax certificate; this requirement was deemed to duplicate the state investigation and examination of an applicant. Perhaps the requirement of registration is additional regulation. The fourth conflict was the requirement of paying a municipal fee based on the gross receipts of the contractor; the state statute required a payment of a fee. The nuunicipal fee appears to have been a revenue measure; if the municipal tax conflicted with state licensing, the court was certainly breaking new ground. The fifth point of conflict was the revocability of the municipal license upon violation of the municipal code; the state had provided disciplinary proceedings for the licensees. This municipal provision would seem to conflict with the general law according to prior cases. Had the court been selective in determining the areas of conflict, one would have no quarrel with the opinion. But the court lumped together all of the above provisions and concluded that the nunicipal ordinance under attack was invalid to the extent that it conflicted with the general law. But what is more significant

court has heretofore struck down, under the commerce clause, state taxes upon the privilege of carrying on a business that was exclusively interstate in character. The constitutional infirmity of such a tax persists no matter how fairly it is apportioned to business done within the state."

6851 Cal. 2d 1, 330 P.2d 385 (1958).

69 Horwith v. City of Fresno, 74 Cal. App. 2d 443, 168 P.2d 767 (1946), and City and County of San Francisco v. Boss, 83 Cal. App. 2d 445, 189 P.2d 32 (1948), made clear that their holdings did not prohibit the city from regulating the quality or character of work to be performed by the contractor. 
are the concluding words in the opinion: "Of course, as contended by defendants, a municipality may tax electrical contractors, as other trades, professions and businesses are taxed. The fees in the present case, however, are exacted not as a business tax but as the price of a license that the city cannot require."70 Taken literally, the above excerpt suggests that the cities, chartered or not, can no longer impose a license tax upon those licensed by the state. It means that the cities may impose a tax, but the tax collection must be enforced by means other than a license. ${ }^{71}$ Unfortunately there is no discussion as to the reasons impelling the departure from prior law.

The above opinion might have been excused as loose language inasmuch as there were regulatory features in the municipal code in question. But the court left no doubt in Agnew v. City of Culver City ${ }^{72}$ that it meant what it said in Agnew v. City of Los Angeles. The same ordinance discussed in the first Agnew v. City of Culver City, decided by the district court of appeal, was before the supreme court. The court in this opinion, however, ascribed the invalidity to the criminal provisions for the enforcement of the tax.

The effect of these supreme court opinions was confusion. One might speculate that the court was objecting to the criminal enforcement of a municipal license tax, perhaps on the ground that a person confined in a jail cannot practice the trade for which he has been hicensed by the state, wliereas a civil action would not impose such legal restraint. ${ }^{73}$ But if the court was objecting to the criminal enforcement of a municipal revenue license as a matter of general principle, rather than on the basis of municipal criminal provisions duplicating state criminal provisions, the court must have been unaware of section 16240 of the Business and Professions Code. This section makes it a misdemeanor for any person to carry on any business without a hicense required by "any law of this State," and has been construed to include municipal licenses. ${ }^{74}$

7051 Cal. $2 \mathrm{~d}$ at $7,330 \mathrm{P} .2 \mathrm{~d}$ at 388.

71 If a license tax is invalid because it is a privilege tax, rather than because of the means of enforcement, it remains for speculation as to whether a city might be able to impose a tax without the nomenclature of a privilege tax but using the same measure, such as a flat fee, upon the same taxpayers. In other words, if a license tax is bad because it is a tax on the privilege of doing a business, can the city impose a tax in the same amount simply as a tax which is collectible only by a debt action?

7251 Cal. 2d 474, 334 P.2d 571 (1959).

73 A civil action, however, may amount to an economic restraint.

74 Car. Bus. \& Prof. Code $\S 16240$, prior to its codification in that code in 1941, Cal. Stats. 1941, ch. 61, § 1, at 720, appeared as CAL. PEN. CoDE § 435, and, as such, had been held to include mumicipal ordinances. Ex parte Bagshaw, 152 Cal. 701, 93 Pac. 864 (1908). But by its codification into the Business and Professions Code, some ambiguity was created since the section appeared in the chapter dealing with state hicenses. In re Groves, $54 \mathrm{Cal}$. 
The decisions, however, might be read more broadly to hold that no license tax can be exacted by the cities where a person has been licensed by the state. This is not an unreasonable interpretation. For example, a district court of appeal said:

The general law is complete in itself. It is not simply prohibitory. It is also permissive. It authorizes contractors licensed by the board to engage in their occupations anywhere in the state. The requirement for the payment of a fee and the obtaining of a permit nullifies the permission given a contractor by the general law to conduct his business at any place in the state..$^{75}$

In addition, the supreme court in Agnew v. City of Los Angeles said, "The fees in the present case, however, are enacted not as a business tax but as the price of a license that the city cannot require." ${ }^{\prime 6}$ But if this were the rationale, the court could not logically stop at protecting state hicensees only. All businesses, trades, and professions which are not prohibited or regulated by the state might be said to be permitted by the state. The fact that a business, trade, or profession is of a type which does not need regulation for the protection of the public should not place it in a disfavored class. The court might well have proceeded to strike down all hicense taxes. ${ }^{77}$

This speculation became academic, however, when the supreme court made an abrupt change and returned to a more orthodox position. The court, in In re Groves, held: "Whether or not state law has occupied the field of regulation, cities may tax businesses carried on within their boundaries and enforce such taxes by requiring business licenses for revenue and by criminal penalties." simply on the ground that "the license fees were not imposed solely for revenue purposes but as an inseparable part of a regulatory scheme excluded by state law."79 But many others would not have so interpreted Agnew v. City of Culver City. For example, the ordinance involved in In re Groves had expressly stated that the criminal penalties provided by the municipal code shall not apply in the enforcement of a municipal license to businesses or professions licensed by the state.

One can only speculate as to whether the supreme court had in the two Agnew cases embarked upon a more stringent control over local taxes which burden intrastate business. If this was the design, the court

2d 154, 351 P.2d 1028, 4 Cal. Rptr. 844 (1960), held that $\S 16240$ has the same effect as did Penal Code $\S 435$.

75 Agnew v. City of Culver City, 147 Cal. App. 2d 144, 150, 304 P.2d 788, 793 (1956).

76 See note 70 supra.

77 But see In re Hubbard, 62 A.C. 116, 396 P.2d 809, 41 Cal. Rptr. 393 (1964).

7854 Cal. 2d 154, 156, 351 P.2d 1028, 1030, 4 Cal. Rptr. 844, 846 (1960).

${ }^{79}$ Id. at 157,351 P.2d at 1031, 4 Cal. Rptr. at 847 . 
unfortunately went too far. At any rate, Groves signaled a retreat so that state licensed occupations are no longer immune per se.

\section{B. The Bradley-Burns Uniform Local Sales and Use Tax Law}

The Bradley-Burns Uniform Local Sales and Use Tax Law, enacted in $1955_{,^{80}}$ expresses several significant policies of the state. First, counties were given the authority to adopt a one percent sales and use $\operatorname{tax}^{81} \mathrm{~A}$ very important limitation imposed upon such authority was that provisions of the county sales and use tax must incorporate the substantive provisions of the state sales and use tax law to achieve uniformity. ${ }^{82}$ The reason for this himitation was apparently to simplify the administration, to reduce the cost of collection, and to ease the burden of compliance by taxpayers. Central to the new authorization was the requirement that a county enter into a contract with the State Board of Equahization allowing the latter to perform the administration of the tax. ${ }^{83}$.

A second aspect of this new law, appears to be the legislature's desire to set a maximum rate of tax at one percent whether the tax is imposed by a county or a city or both. ${ }^{84}$ The law provides that a county must give credit for city sales or ${ }_{1}$ use tax paid by the taxpayer to a city within the county, but the credit is required only if the city has both adopted the state sales and use tax provisions ${ }^{85}$, and contracted with the State Board of Equalization to have the latter administer the city tax. ${ }^{88}$

The issue which arises is whether a city under the Bradley-Burns system can impose an additional license tax upon the retailers of tangible personal property, however the tax may be measured, without jeopardizing the city's revenue from the Uniform. Sales and Use Tax Law and without subjecting its taxpayers to a denial of credit for the city tax. Literally, the Uniform Sales and Use Tax Law permits the credit of the city tax against the county tax if "the city: sales and use tax is levied under an ordinance including provisions in substance as follows: (1) A provision imposing a tax for the privilege of selling tangible personal property at retail upon every retailer in the city at the rate of 1 percent or less of the gross receipts .... (2) Provisions identical to those contained in Part 1 of Division 2 of this code [state sales and use tax. laws], insofar

80 Cal. Stats. 1955; ch. 1311, § 1, at 2381; CaL. Rev. \& TAX. Code \$§ 7200-09.

81 CaI. Rev. \& TAX. CODE $\$ 7201$.

82 CAL. REv. \& TAX. Code $\$ 7202$ (b). There are minor differences, however, in that certain exemptions not found in the state tax are required in the local tax. CaI. REv. TAx. Code $\$ \S 7202(f), 7203(4)$. Similar differences exist in city provisions. CAL. REv. \& TAX. CODE $\S \S$ $7202(\mathrm{~h})(6),(7)$.

83 CAI. REv. \& TAX. CODE $\$ 7202$ (d).

84 CAL. REv. \& TAX. CODE $\$ 7202$ (a).

85 CAL. REv. \& TAX. CODE $\$ \S 7202(h)(1),(2)$.

86 CAI. Rev. \& TAX. Code $\$ 7202(\mathrm{~h})(4)$. 
as they relate to sales and use taxes .... ." One interpretation of the above requirements is that so long as there is one body of city tax provisions identifiable as the sales and use tax law conforming to state law, the credit provisions operate and the city is entitled to the revenue thereunder. This view stresses the requirement of uniformity only for the purpose of facilitating the central administration of identical tax laws adopted by different levels of government; ${ }^{88}$ the existence of other provisions imposing additional taxes upon the retailer would not upset this scheme of central administration since the other provisions would not be admimistered by the State Board of Equalization. Appealing as this argument may be, it ignores the fact that a major impetus for the uniform provisions came from retailers burdened by the number and diversity of city taxing laws. ${ }^{89}$ It fails to explain why the legislature has imposed a maximum tax rate of one percent. One may reasonably conclude that the legislature had placed this maximum rate in the belief that (1) the consumers in this state should not be burdened by a consumption tax greater than four percent-three percent for the state and one percent for the county and city combined-upon a purcliase of tangible personal property, and (2) the uniformity in rate is desirable to protect retailers against competition from retailers in political entities imposing a lower tax rate. ${ }^{90}$

The likely reason for the voluntary method established under the Bradley-Burns Uniform Local Sales and Use Tax Law to achieve this state objective is that the legislature probably thought that it was powerless to dictate tax policy to the cliartered cities. ${ }^{91}$ Undoubtedly, the residents of the chartered city will strongly urge compliance with the Bradley-Burns law. The retailers within a non-complying city may suffer

87 Cax. Rev. \& TAX. Code $\S \S 7202(h)(1),(2)$.

$88 \mathrm{~A}$ closely related argument might be based on the language of the statute which requires identity of provisions "insofar as they relate to sales and use taxes." It might be said that this provision inferentially permits other forms of local occupation taxes on the retailers so long as such taxes are not in form a sales and use tax. The fallacy of this argument is that the identity is required as to substantive provisions of the state sales and use tax law, in contrast to other matters which are required but may be provided for "in substance," such as incorporation of future amendments to the state law to make central administration effective. Thus, the identity requirement does not shed much hight on the issue in question.

89 Interview with Professor Adrian A. Kragen, University of California, July 12, 1965, who acted on behalf of the California Retailers Association in relation to the adoption of the Uniform Sales and Use Tax Law.

80 Although the rate of a city sales and use tax may be less than $1 \%$, the combined city and county tax rate will always be $1 \%$ since the county rate is required to be $1 \%$. CAI. REV. \& TAX. Code $\S \S 7202,7203$.

91 The adoption of a sales and use tax ordinance is a "municipal affair." See West Coast Advertising Co. v. City and County of San Francisco, 14 Cal. 2d 516, 95 P.2d 138 (1939). 
since consumers from outside the city would no longer make purchases within the non-complying city if the consumers had to bear a tax burden in that city and a use tax at their residence. The temptation upon city fathers to comply would be irresistible since the result of non-compliance is either a tax by the city and an added tax by the county, thereby prejudicing the city's retailers, or a diversion to the county of revenues which otherwise would fall into the city coffers. Another benefit of compliance accruing to the city is an overall improvement in enforcement through state administered auditing. ${ }^{92}$

If uniformity of provisions and burdens was the legislative desire, one might conclude that an additional occupation tax upon retailers of tangible personal property ${ }^{93}$ cannot be imposed without forfeiture of benefits under the Bradley-Burns Act. The absence of documented legislative history, however, precludes a compelling conclusion. ${ }^{04}$

\section{Burden on Intrastate Commerce}

The basic policy underlying the commerce clause of the Federal Constitution-to preserve the free fiow of commerce among the states to optimize economic benefits ${ }^{05}$-is equally applicable to intercity commerce within the state. If fifty independent economic units within the United States are undesirable, 387 economic enclaves within California would be intolerable. A tax burden which places intercity commerce at a disadvantage in comparison to a wholly intracity business may have such an effect. The clearest illustration of this proposition is a tax whicl discriminates against goods or services from outside the city. Such a tax operates as a protective tariff in favor of the business and trade within the city and discourages the free flow of goods and services from outside the city. An artificial barrier to competition imposed by a discriminatory tax can only help to sustain the less efficient business or to maintain a monopolistic position; either result brings the probability of higher costs to the consumer. If, in retaliation, discriminatory taxes were adopted by

02 See Report of the Senate Intermar Comm. on State and Local Taxation, Locat, Governament FLNANCE IN CalTFornta 1940-1953 108 (1955).

03 If the compliance cost of the retailers was the major evil souglt to be corrected, a flat fee license would not frustrate the legislative purpose.

04 At least some of the cities do not believe the Bradley-Burns Act is exclusive. In the City of Berkeley a retailer of tangible personal property is taxed upon the basis of average number of employees. BERKeLEY, CAL., BUS. LIC. ORD. $\$ 5.1$ as amended (1964). In the City of Hayward, a retailer is still subject to a tax based upon gross receipts. Haxward, Cax., MUNICIPal CODE \& 8-1.88. Both these cities are under the Bradley-Burns Act.

05 For a policy discussion of free interstate commerce, see Developments, Federal Limitation on State Taxation of Interstate Business, 75 Harv. L. REv. 955, 956-960 (1962). See also Independent Wareliouses, Inc. v. Scheele, 331 U.S. 70 (1947) (dissenting opinion). 
other cities, the state could become divided into fragmented economic markets.

A tax which does not on its face discriminate against outside business may, like a protective tariff, deter the conduct of intercity business if repeated by many cities. For example, flat fee occupation taxes imposed by the cities will be more burdensome upon those who conduct sporadic business in a number of cities than upon those who conduct their business entirely in one city.

A tax whicl operates as a toll would be not only an impediment to mobility of persons and goods but would be borne by taxpayers who have no political voice within the taxing entity.

Competing against the above policies is the legitimate interest of the taxing entity in having those who enjoy the benefits of government and services sliare in their cost. There would seem to be no more a rational reason to favor than to discriminate agamst those engaged in intercity commerce.

The task then is to accommodate these competing interests. The law dealing with tax burdens on intrastate commerce must be examined with this goal in mind.

\section{The Legal Basis}

Within the federal structure, the tax burdens which affect interstate commerce have been policed primarily under the commerce clause. ${ }^{96}$ Any student of the commerce clause appreciates that the standards evolved by the Court to test the validity of local taxes upon interstate commerce have been neither consistent nor always meaningful. ${ }^{97}$ But the important point liere is that there exists a provision in the United States Constitutionthe commerce clause- to resolve these problems. The due process clause ${ }^{98}$ has also provided a framework within which these problems have been analyzed. ${ }^{99}$ At times the distinction between the commerce clause and the due process clause has been blurred, ${ }^{100}$ but basically the due process clause has been restricted to issues related to territorial jurisdiction of the taxing entity over the subject of the tax. ${ }^{101}$ The equal protection

96 U. S. Const. art. I, $\S 8$.

97 For a discussion of the transition from the "direct burden test" to "cumulative burden test" back to "direct burden test," see Barrett, State Taxation of Interstate Commerce, 4 VANd. L. Rev. 496 (1951); Hartaran, State Taxation of Interstate Comparerce 21-48 (1953). More recently, the Supreme Court has spoken only in terms of cumulative burdens. See General Motors Corp. v. Washington, 377 U.S. 436 (1964).

88 U. S. Const. amend. XIV, \& 1.

89 See, e.g., Central R.R. v. Pennsylvamia, 370 U.S. 607 (1962); Miller Bros. Co. v. Maryland, 347 U.S. 340 (1954); McLeod v. J. E. Dilworth Co., 322 U.S. 327 (1944).

100 See Hartaran, op. cit. supra note 97 at 13-20.

$101 \mathrm{Ibid}$. Issues concerning jurisdiction to tax have in turn led to frequent discussion 
clause $\mathrm{e}^{102}$ has been used infrequently to invahidate taxes. Even when the taxes discriminated against interstate commerce, the Court has relied upon the commerce clause, ${ }^{103}$ perhaps because the legislative classification which otherwise might be rational becomes unacceptable due to the policy underlying the commerce clause.

In contrast, the state constitutions do not have a provision comparable to the commerce clause. This is not to say that tax burdens upon intrastate commerce have gone unchecked, but to the extent that the courts have attempted to regulate these burdens, they have had to rely upon other conceptual bases.:-

The concept used most widely and indiscriminately by the California courts is invalidity arising from discrimination. More often than not, the courts simply are not explicit as to the constitutional or statutory basis for this proscription. ${ }^{104}$ Article $I$, section 21, of the California constitution, which prohibits the granting of privileges and immunities to a citizen or a class of citizens not granted to others, is sometimes cited. ${ }^{105}$ The language of equal protection, without citing the fourteenth amendment of the Federal Constitution, is also employed in some cases. ${ }^{106}$ "Privileges and immumities" and "equal protection" are at times mentioned together. ${ }^{107}$

of the need for or the propriety of an apportionment, although apportionment problems are also discussed under the commerce clause. E.g., Hans Rees' Sons, Inc. v. North Carolina, 283 U.S. 123 (1931) (taxpayer arguing that the state apportionment of its net income violated the commerce and due process clauses; the court appears to invalidate the apportioninent on due process grounds); Jobnson Oil Ref. Co. v. Oklalioma, 290 U.S. 158 (1933) (duc process clause relied upon to require the state to determine average number of cars in the state for property tax purposes); Standard Oil Co. v. Peck, 342 U.S. 382 (1952) (apportionment required for property tax purposes on the ground that inultiple taxation of interstate operations would otherwise result and there was also a lack of relation to the benefits and protection which the taxing state gives to those operations).

102 U.S. ConsT. amend. XIV, 81.

103 See, e.g., West Point Wholesale Grocery Co. v. City of Opelika, 354 U.S. 390 (1957); Memphis Steam Laundry Cleaner, Inc. v. Stone, 342 U.S. 389 (1952); Nippert v. City of Richmond, 327 U.S. 416 (1946); Best \& Co. v. Maxwell, 311 U.S. 454 (1940). Article IV, 82 of the Federal Constitution which provides, "The citizens of each State slall be entitled to all privileges and immunities of citizens in the several States," has been used to invalidate a discriminatory tax based upon the location of the taxpaycr's "chief office." Clalker v. Birmingham \& N.W. Ry., 249 U.S. 522 (1919). And in a dictum in Sbaffer v. Carter, 252 U.S. 37, 52 (1920), the Court relying upon the above provision, states, "That a State, consistently with the Federal Constitution, may not prolibit the citizens of other States from carrying on legitinuate business within its borders like its own citizens, of course is granted ...."

${ }^{104}$ E.g., Security Truck Line v. City of Monterey, 117 Cal. App. 2d 441, 257 P.2d 755 (1953); In re Hart, 36 Cal. App. 627, 172 Pac. 610 (1918).

105 E.g., Town of St. Helena v. Butterworth, 198 Cal. 230, 244 Pac. 357 (1926); In re Robinson, 68 Cal. App. 744, 230 Pac. 175 (1924).

106 E.g., Bueneman v. City of Santa Barbara, 8 Cal. 2d 405, 65 P.2d 884 (1937);

Ferran v. City of Palo Alto, 50 Cal. App. 2d 374, 122 P.2d 965 (1942).

107 E.g., Soares v. City of Santa Maria, 38 Cal. App. 2d 215, 100 P.2d 1108 (1940). 
The concept of discrimination has been used flexibly. ${ }^{108}$ The courts have employed this rationale not only to strike down taxes which on their face were discriminatory but to strike down taxes on values outside the taxing entity. For example, a hicense tax imposed on the privilege of engaging in the laundry business in the city and measured by the number of employees, regardless of where employed, was struck down because the $\operatorname{tax}$ was deemed discriminatory. ${ }^{109}$ The reason for the invalidity probably was either the lack of the taxing entity's jurisdiction to tax values outside the city ${ }^{110}$ or the possibility of cumulative taxes upon the same activity, ${ }^{111}$ but these reasons were swept under the label of discrimination.

Another concept used in some cases is that a tax which acts as a restraint of trade or as a protective tariff is invalid; ${ }^{112}$ these labels, however, may be nothing more than synonyms for invalid discrimination. There is, of course, no state constitutional or statutory provision precisely expressing either rationale. A notion such as restraint of trade undoubtedly can be extensively used to strike down those taxes which burden intrastate commerce, but the notion has not been fully exploited by the courts.

Finally, the courts have construed the enabling legislation on which the taxing entity relied as not authorizing a tax which might otherwise burden intrastate commerce. For example, where the law authorized a tax on "business,". it was held that a tax upon a person in the passenger transportation business who merely passed through the city without any loading or unloading was unauthorized because the taxpayer was not engaged in a "business" in the city. ${ }^{113}$ In other contexts where the city has attempted to single out a specific activity of a business as the subject

108 In In re Robinson, 68 Cal. App. 744, 230 Pac. 175 (1924), the court held that the tax was bad as applied to intrastate commerce because of the state privileges and immunities clause and as applied to interstate commerce because of the commerce elause.

109 Ferran v. City of Palo Alto, 50 Cal. App. 2d 374, 122 P.2d 965 (1942).

110 The court concluded, "It is an invalid attempt by the city to make its ordinance extraterritorial in scope and application." Id. at 383,122 P.2d at 970.

111 In another case, where a tax was based on gross receipts from sales, the court held: "To allow a city to levy a liceuse tax based upon gross receipts attributable to selling activities outside the city would be an unreasonable discrimination and a demial of equal protection of the law. ... If such taxation were allowed it would unjustly discriminate against those firms whose selling activities in Los Angeles compose but a small fraction of the total sales effort and whose gross receipts are in large part attributable to selling activities in other areas.". City of Los Angeles v. Belridge Oil Co., 42 Cal. 2d 823, 832, 271 P.2d 5, 11 (1954), appeal dismissed, 348 U.S. 907 (1955). The discrimination posed by the court can arise because there might be cumulative burdens or because the tax burden is not commensurate to the benefits derived as compared to other taxpayers.

112 La Franchi v. City of Santa Rosa, 8 Cal. 2d 331, 65 P.2d 1301 (1937) (regulatory measure); Ex parte Frank, 52 Cal. 606 (1878) (restraint of trade but also mentions discrimination); In re Hart, 36 Cal. App. 627, 172 Pac. 610 (1918).

118 Matter of Smith, 33 Cal. App. 161, 164 Pac. 618 (1917). See also Franklin v. Peterson, 87 Cal. App. 2d 727, 197 P.2d 788 (1948). 
of the tax, the court has invalidated the tax on the ground that the authorizing act permitted a tax only upon the entire business. ${ }^{114}$ Thus, statutory interpretation may serve as another method to police tax burdens.

\section{Specific Situations}

(a) Taxing the Privilege of Engaging in Intercity Commerce.-The United States Supreme Court has held that a state cannot tax the privilege of doing business if that business is wholly interstate in nature even though the measure of the tax is the activities occurring within the taxing state. ${ }^{115}$ The ostensible reason for the prohibition is that Congress has been delegated the exclusive power to regulate this privilege. The result is rather formalistic since the states are permitted to derive the same revenues by the same ineasures so long as the legal incidence of the tax is not on the privilege. ${ }^{116}$ Whether the Court has been motivated by the more substantial reasons that might be advanced to sustain the result is speculative. It might be suggested that the grant of complete immunity to the privilege of engaging in interstate commerce is a prophylactic measure since the Court felt that it could not adequately regulate the measure of the tax once the riglit to tax the privilege was conceded..$^{117}$ It has also been suggested that the power to tax the privilege of conducting interstate business may have adverse consequences in terms of other attendant powers including the power to exclude completely for the nonpayment of the tax. ${ }^{118}$

114 Merced County v. Helm \& Nolan, 102 Cal. 159, 36 Pac. 399 (1894); see Bramman v. City of Alameda, 162 Cal. 648, 124. Pac. 243 (1912).

115 Spector Motor Serv. Inc. v. O'Connor, 340 U.S. 602 (1951); Puget Sound Co. v. State Tax Comm'n, 302 U.S. 90 (1937); Robbins v. Shelby County Taxing Dist., 120 U.S. 489 (1887) (a tax on out-of-state drummer deemed a prohibited tax on interstate commerce itself); cf. Interstate Oil Pipe Line Co. v. Stone, 337 U.S. 662 (1949) (four justices sustained a privilege tax expressly claiming that whether the taxpayer's business was wholly interstate was immaterial).

116 Northwestern States Portland Cement Co. v. Minnesota, 358 U.S. 450 (1959).

The earher cases held that where the taxpayer is engaged in intrastate and interstate business within the state, a privilege tax upon the taxpayer is valid only if (1) the tax is levied upon the intrastate activity, (2) the interstate activity does not increase the tax, and (3) the nature of the business is such that the taxpayer is free to withdraw from the local activity without adversely affecting the interstate business. See, e.g., Cooney v. Mountain States Tel. \& Tel. Co., 294 U.S. 384 (1935); Sprout v. City of South Bend, 277 U.S. 163 (1928); Leloup v. Port of Mobile, 127 U.S. 640 (1888). The last qualification was rejected in Pacific Tel. \& Tel. Co. v. Tax Comin'n, 297 U.S. 403 (1936). Even the second qualification may be questionable after City of Chicago v. Willett Co., 344. U.S. 574 (1953), which states that the taxpayer must sliow that interstate activity is burdened by a tax upon the local activity.

117 See Overton, State Taxation of Interstate Commerce, 19 TeNN. L. REv. 870, 902903 (1947).

118 Developments, 75 Harv. L. Rev. 1032-33 (1952). See also Hartakan, State Taxation of INTERstate COMMIERce, 105 (1953). 
At one stage, the California courts appeared to liave arrived at the same result. A municipal license tax, levied upon persons regulated and licensed by the state, was held invalid on the ground that a state license granted a riglit to engage in the licensed occupation whicl right a city could not impair. ${ }^{119}$ This result, however, is now discredited. ${ }^{120}$

In the absence of a provision in the state constitutions comparable to the commerce clause it would appear difficult for the state courts to fashion a rule which would totally prohibit a privilege tax on intercity commerce. That such a rule lias not been adopted with respect to intercity commerce is fortunate because the cities may lave less flexibility in adjusting to such a prohibition through other revenue measures. ${ }^{121}$

(b) Taxation Determined by Business Situs.-Where a tax provision explicitly discriminates adversely on the basis of out-of-state criteria, the tax operates as a protective tariff to shelter the intrastate business and impedes the free flow of commerce. That the United States Supreme Court should invalidate such tax as violating the commerce clause is not surprising.

Exemplary of these decisions is Memphis Steam Laundry Cleaner, Inc. v. Stone ${ }^{122}$ in whicl the Court invalidated a state tax more burdensome upon those who picked up and delivered laundry but were unlicensed in the taxing state. The Court reasoned:

The Commerce Clause created the nation-wide area of free-trade essential to this country's economic welfare by removing state lines as impediments to intercourse between the states. The tax imposed in this case made the Mississippi state line into a local obstruction to the flow of interstate commerce that cannot stand under the Commerce Clause. ${ }^{123}$

Similarly, in West Point Wholesale Grocery Co. v. City of Opelika, ${ }^{124}$ a tax upon those delivering groceries at wholesale from a point without the taxing city was invalid as applied to an out-of-state wholesaler because the tax was much greater on the out-of-state wholesaler than on the local wholesaler. Also relevant are the United States Supreme Court cases ${ }^{125}$ which have dealt with the privileges and immunities clause of article IV, section 2, of the Federal Constitution. The language of that

110 See text commencing from note 57 supra.

120 See text commencing from note 78 supra.

121 Either because of limited authority or because of state pre-emption of other revenue sources, the city might not be able to impose other types of tax, such as the net income tax, to make intercity commerce pay its way.

122342 U.S. 389 (1952).

$123 \mathrm{Id}$. at 395.

124354 U.S. 390 (1957).

125 See, e.g., Mullaney v. Anderson, 342 U.S. 415 (1952); Toomer v. Whitsell, 334 U.S. 385 (1948) ; Chalker v. Birmingham \& N.W. Ry., 249 U.S. 522 (1919). 
clause is very similar to that language found in article I, section 21, of the California constitution. The Court has said:

... [I]t was long ago decided that one of the privileges which the clause guarantees to citizens of State $\mathrm{A}$ is that of doing business in State B on terms of substantial equality with the citizens of that State.

Like many other constitutional provisions, the privileges and immunities clause is not an absolute. It does bar discrimination against citizens of other States where there is no substantial reason for the discrimination beyond the mere fact that they are citizens of other States. But it does not preclude disparity of treatment in the many situations where there are perfectly valid independent reasons for it. ${ }^{126}$

Although the rule evolved by the above cases seems apposite to intrastate business, the Cahifornia courts have developed a peculiar body of law in this respect. Early California cases invalidated municipal license taxes which sought to discriminate in favor of a business within the city. Thus, the court in 1878 rejected a tax inposed on those selling within the city, but without goods in the city, whicl was twenty times higher than the tax on those selling with goods in the city. ${ }^{127}$ While the distinction was in terms of location of goods to be sold, the tax effectively discriminated between those with and those without places of business in the city. The court stated: "It also contravenes the public policy of the State, in that it obstructs commercial intercourse between the principal seaport city of the State and the interior; the policy being to foster and encourage commercial intercourse and free interchange of commodities between the several sections." 128

This is a clear exposition of free intercity commerce, comparable to the pohicy of free interstate commerce mentioned in the Memphis Steam Laundry Cleaner case. ${ }^{129}$ This rule was followed for a while. In 1917 a tax of 120 dollars on each vehicle used for delivery of laundry into the city from a laundry located outside the city and a tax of 120 dollars on an agency maintained in the city.by an outside laundry were deemed discriminatory as compared to a tax of twelve dollars on a laundry located within the city. ${ }^{130}$ "The hicense provisions in question are plainly devised as a protective tariff for the benefit of laundries located in the

126 Toomer v. Whitsell, supra note 125 at 396 . One of the valid reasons for discrimination is the additional cost of enforcement against nonresidents; the taxpayer has the burden of disproving that the discrimination is not justified. The burden might be met, however, if the taxpayer attempts to elicit information as to the cost of enforcement which the taxing officials refuse to divulge. Mullaney v. Anderson, supra note 125.

127 Ex parte Frank, 52 Cal. 606 (1878).

128 Id. at 611 .

128 See text accompanying note 122 supra.

130 Matter of Hines, 33 Cal. App. 45, 164 Pac. 339 (1917). 
city. ...2131 Similar types of discrimination met a similar fate in later cases. ${ }^{132}$.

In E. A. Hoffman Candy Co. v. City of Newport Beach, ${ }^{133}$ however, a breach appeared in this salutary rule. In that case, a license tax of twelve dollars was imposed on local business, although motor trucks might be used, while a tax of ten dollars per truck used for hauling goods was imposed on others. The taxpayer, who conducted a mercantile business in another city but made deliveries into the taxing city, argued that there was discrimination, but this argument was summarily rejected.

The court relied upon Ex parte Haskell. ${ }^{134}$ Reliance upon Haskell, however, is questionable. Haskell seems to lave involved a tax upon itinerant vendors and solicitors which differed from a tax on those conducting business at established places in the taxing city. ${ }^{135}$ The tax was sustained only because the classification was based on the mode of doing business; the court in Haskell clearly indicated that a classification based on residency alone would be invalid. In contrast, the criteria in $E$. $A$. Hoffman Candy Có. was based on the locality of operation because those with a local business paid a maximum tax of twelve dollars regardless of the number of velicles used whereas those operating from outside the city and using two or more trucks within the city were required to pay more than the in-city business. ${ }^{136}$

The next significant case is Bueneman v. City of Santa Barbara, ${ }^{137}$

131 Id. at 47,164 Pac. at 340.

132 In re Robinson, 68 Cal. App. 744, 230 Pac. 175 (1924); In re Hart, 36 Cal. App. 627,172 Pac. 610 (1918); In re Riley, 39 Cal. App. 58, 177 Pac. 854 (1918).

133120 Cal. App. 525, 8 P.2d 235 (1932).

134112 Cal. 412, 44 Pac. 725 (1896). A tax on itinerant personnel is more fully discussed later.

135 The ordinance in question imposed the tax on "persons, outside of those conducting regular places of business ...." A different tax was imposed upon those "wbo at fixed place of business sell" goods. Thus it is unclear as to how a merchant with a fixed place of business in the city or outside the city with itinerant representatives would be treated.

130 The City of Hayward imposes a hicense tax of $\$ 10$ per vehicle per quarter, or a total of $\$ 40$ per year, upon those who collect articles to be cleaned or laundered. HaYward, CaI., MuNICIPAI CODE § 8-1.58. In contrast, those who maintain a cleaning or laundry shop without maintaining a plant in the city are taxed on the basis of gross receipts irrespective of the number of vehicles used in the business; these taxpayers with aunual gross receipts from $\$ 40,000$ to $\$ 49,999$ are taxed $\$ 39.00$ a year. Those with plants in the city must have annual gross receipts of $\$ 12,500$ to $\$ 19,999$ to be taxed $\$ 36$ per year. Hayward, Cat., MUNICIPAL CODE § 8-1.57. The tax scheme of the City of Alameda also contains a discrepancy of burden upon those dry cleaners with an established place of business and those without. Those with establisbed places of business pay $\$ 15$ for the first person working in the business and $\$ 3$ per person for the next nine persons. ALAXmedA, CAL., CrTY ORD. No. 1186 NS $\S \S 13-1918,13-193$. On the other hand, those without an established place of business but engaged in pickup and delivery from retail customers must pay $\$ 15$ per vehicle. ALAXIEDa, CAL., CITY ORD. No. 1186 NS \& 13-1918.

1378 Cal. 2d 405, 65 P.2d 884 (1937). 
decided in 1937. Bueneman held invalid a tax of 200 dollars upon those who solicited or dehvered laundry and dry cleaning in the taxing city; those who maintained in the city a plant where the laundry or cleaning work was done were exempt. The tax was deemed bad because those taxed and those exempted conducted identical businesses except for the location of the plant. Clearly, the city had attempted to protect the local estabhishments from outside competition.

The import of the prior cases was completely lost upon the court in Continental Baking Co. v. City of Escondido, ${ }^{138}$ also decided in 1937. In that case, the city imposed a tax of fifty dollars upon persons conducting bakery business in the city if the bakery was on the tax roll of the city. But those businesses whose bakery was not on the tax roll of the city were taxed a minimum of 150 dollars. Despite this apparent discrimination, the court sustained the tax, summarizing the law to be:

... [F] or the purpose of fixing and imposing license taxes mercliants having fixed places of business within a city and other merchants may be separately classified and license taxes in different amounts may be laid upon those in the two classifications, so long as the tax is actually imposed upon both classes, and provided that the tax on one class is not so disproportionately heavy as to demonstrate that the classification is "a mere subterfuge for legislation directed against a particular group of taxpayers."138

The classification was justified on the ground that local business contributed to the revenue of the city through the payment of property tax.

It is submitted that the court misconstrued the prior cases and arrived at an unjustifiable result. The prior law prohibited discrimination between local and outside business because a greater burden was placed on the outside business. Furthermore, without an ascertainable criterion such as added cost of enforcement, the court is not equipped to determine how much discrimination against outside business is tolerable. The fact that the outside business might not pay as much property tax to the taxing city does not appear to be a proper consideration. The outside business is taxed for any property which has a situs within the taxing city, and thus pays for the benefit conferred on this property. The attempt to increase the occupation tax on the outside business makes the outside business bear a cumulative burden. It pays property tax outside the city and an additional tax within the city for the reason that its property is located outside the city.

Finally, in Sivertsen v. City of Menlo Park ${ }^{140}$ the taxing city levied

$139 \mathrm{Id}$. at $393,69 \mathrm{P} .2 \mathrm{~d}$ at 183 . By this criterion, the local business might operate through itinerant personnel and still be subject to the lesser tax.

14017 Cal. 2d 197, 109 P.2d 928 (1941). Although the Menlo Park ordinance on its 
a license tax of ten dollars upon those painters who had a fixed place of business in the city and a tax of twenty dollars upon those who did not. The discrimination against outside painters was sustained on the ground that it was not excessive. The court, however, mentioned no criteria for making this evaluation. ${ }^{141}$

Many other states have lield invalid those hicense tax provisions which on their face discriminated against persons who operated their business from outside the city. A clear case is where the discriminatory criterion is residency within the taxing city. ${ }^{142}$ Another form in wlich discrimination appears is the greater burdens imposed upon those who have out-ofcity operations, such as a laundry plant or bakery located outside the taxing city ${ }^{143}$ or those who have goods delivered from outside the city. ${ }^{144}$ A common situation, where the discrimination is a little less apparent, is the imposition of a tax upon itinerant merchants, either soliciting or peddling, while those who operate an established place of business within the taxing city are either exempt or required to pay a lesser tax. ${ }^{145}$ In

face may appear to distinguish the two classes of taxpayers on the basis of mode of operation, in fact such is not the case since a painter normally does his painting at the customer's place. Thus, a painter operating out of his residence within the city would have a place of business within the city.

141 Compare Chalker v. Birmingham \& N.W. Ry., 249 U.S. 522 (1919), in which the Court invalidated a tax upon certain construction contractors. The tax discriminated upon the basis of whether the taxpayer's chief office was within or witlout the state. The court relied upon the privileges and immunities clause of article IV, $\S 2$ of the United States Constitution which is quite similar in language to article $I, \S 21$ of the California constitution. The taxpayer in Sivertsen, relied upon the California provision and the equal protection clause of the Federal Constitution. There is one difference between Chalker and Siversten. In Chalker, a taxpayer can necessarily have but one chief office, whereas in Sivertsen a taxpayer can lave fixed places of business in a number of cities. As a practical matter, however, the discrimination in Sivertsen operates primarily against nonresidents.

142 Danyluk v. Bethlehem Steel Co., $406 \mathrm{~Pa} .427,178$ A.2d 609 (1962) (a flat tax upon nonresident engaged in any occupation in the city deened a capitation tax because unrelated to the amount of business conducted); Ex parte Irisl, 121 Kan. 72, 122 Kan. 33, 250 Pac. 1056 (1926); Eales v. City of Barbourville, 177 Ky. 216, 197 S.W. 634 (1917). See also French, Municipal Tariffs Under the Guise of Occupation Taxes, 18 IowA L. REv. 342 (1933).

143 E.g., Long v. City of Benton, 285 Ky. 526, 148 S.W.2d 701 (1941); Speier's Laundry Co. v. City of Wilber, 131 Neb. 606, 269 N.W. 119 (1936); City of Newman v. Atlantic Laundries, 174 Ga. 99, 162 S.E. 497 (1932); Ward Baking Co. v. City of Fernandia, 29 F.2d 789 (S.D. Fla. 1928).

144 E.g., Rochell v. City of Florence, 237 Ala. 635, 188 So. 247 (1939); cf., Ex parte Smith, 100 Fla. 1, 128 So. 864 (1930) (discrimination against goods manufactured outside the state invalid under the 14th amendment to the United States Constitution).

145 Olan Mills, Inc. v. City of Niagara Falls, 206 Misc. 1105, 136 N.Y.S.2d 668 (Sup. Ct. 1955); Olan Mills, Inc. v. City of Sharon, 371 Pa. 609, 92 A.2d 222 (1952); Colonial Baking Co. v. City of Fremont, 296 Mich. 185, 295 N.W. 608 (1941); O'Connell v. Kontojolın, 131 Fla. 783, 179 So. 802 (1938); American Bakeries Co. v. City of Griffin, 174 Ga. 115, 162 S.E. 513 (1932); Grantham v. City of Clickasha, 156 Okla. 56, 9 P.2d 747 (1932); Hair v. City of Humboldt, 133 Kan. 67, 299 Pac. 268 (1931). 
these situations, the local merchants, even when they operate through itinerant representatives, would pay the lesser tax; thus, the discrimination is against those operating from without the taxing city,

Unlike later Cabifornia cases, however, cases in other states have not made the invalidity of discrimination depend upon the exemption of local merchants or upon the magnitude of the discrimination. Moreover, several cases liave specifically rejected the argument that the discrimination might be justified on the ground that the outside merchant does not pay the same amount of property tax as does the local merchant. ${ }^{146}$

Althougli the courts liave generally held invahd discrimination based on locality criteria, there has been difficulty in applying this rule. In Florida, there are a number of cases invalidating discrimination against outside merchants, but in Blalock v. Poveledge, ${ }^{147}$ a discriminatory tax upon outside enterprises maintaining display rooms from whicl they solicited orders was sustained on the ground that the discrimination was based on the method of doing business rather than on extraterritorial factors. It is difficult to square this decision with the other Florida cases since the discrimination was based solely on the fact that the taxpayer was representing outside merchants.

South Carolina ${ }^{148}$ and Virginia, ${ }^{140}$ however, lave sustained discrimination against business located outside the taxing city. The justification given was the reasonableness of the classification or the fact that outside business does not pay local property tax..$^{150}$

146 O'Connell v. Kontojohn, supra note 145; Hamilton v. Collins, 114 Fla. 276, 154 So. 201 (1934).

147131 Fla. 498, 179 So. 772 (1938). In Kentucky, there appears an aberration in Williams v. City of Bowling Green, $254 \mathrm{Ky} .11,70$ S.W.2d 967 (1934), in which the court sustained a discriminatory tax which was based on whether a cleaning plant was operated within the city; but the scope of this decision has been narrowly limited by a later case. Long v. City of Benton, 285 Ky. 526, 148 S.W.2d 701 (1941).

148 American Bakeries Co. v. City of Sumter, 173 S.C. 94,174 S.E. 919 (1934); Crosswell \& Co., Inc. v. Town of Bishopville, 172 S.C. 26, 172 S.E. 698 (1934).

140 Manhattan Co. v. County Bd., 197 Va. 765, 91 S.E.2d 408 (1956); Vaughan v. City of Richmond, 165 Va. 145, 181 S.E. 372 (1935).

150 Note that because United States Supreme Court cases have been decided primarily on commerce clause grounds, taxpayers who face intrastate business discrimination can find little support in them. See text accompanying note 96 suprct. The United States Supreme Court has affirmed a case in which a license tax discriminated in favor of those with plants within the city as against others although a denial of equal protection was urged by the taxpayer. Richmond Iinen Supply Co. v. City of Lynchburg, 160 Va. 644, 169 S.E. 554 (1933), aff'd per curiam, 291 U.S. 641 (1934). Compare Wheeling Steel Corp. v. Glander, 337 U.S. 562 (1949) (ad valorem property tax on certain accounts receivable owned by nonresidents of the state but exemption of those owned by residents held invalid), with Allied Stores v. Bowers, 358 U.S. 522 (1959) (property tax discrimination against the residents of the state sustained). Perlaps the rationale underlying these decisions is that stated in the concurring opinion in Allied. Stores, namely, that in a federation, discrimination against residents, unlike discrimination against nonresidents, should be tolerated to permit the state to 
(c) Taxation Based on Mode of Doing Business.-A frequently litigated issue concerns the validity of a tax upon a business conducted througli itinerant personnel, whether they be peddlers or solicitors. With respect to the cases arising under the Federal Constitution, the Uinited States Supreme Court has held invalid, under the commerce clause, a flat fee tax on solicitors, reasoning that such a tax may impose an undue econonnic burden on an interstate business. ${ }^{151}$

The first California case to give thorough consideration to this problem was Ex parte Haskell. ${ }^{162}$ In that case, itinerant salesmen were cliarged a flat fee of fifty dollars per quarter, a burden greater than that imposed upon those operating regular places of business. The court, in upholding the tax, said that the legislative body can take notice of the fact that itinerant vendors might have less expense in the conduct of their business. Subsequent cases have reaffirmed this rule. ${ }^{153}$

A substantial number of other states have similarly sustained a license tax upon itinerant business, ${ }^{154}$ even when the tax was greater than the tax imposed on those operating from established places of business in the city. ${ }^{155}$ There are, however, cases invalidating these taxes. ${ }^{156}$

shape its own economic structure. Moreover, residents have political control over the tax system. If this is the basis, the Supreme Court will stay clear of intrastate tax discriminations. See also Central R.R. v. Pennsylvania, 370 U.S. 607 (1962).

151 Robbins v. Shelby Taxing Dist., 120 U.S. 489 (1887). The opinion also indicates disapproval on another ground, namely, that the activity is interstate commerce without regard to the economic burden. See also Real Silk Hosiery Mills v. City of Portland, 268 U.S. 325 (1925); Best \& Co. v. Maxwell, 311 U.S. 454 (1940); (tax deemed discriminatory because regular retail merchants in the state, who were deemed to be the real competitors of taxpayer-drummers, were taxed at a nominal amount). In Nippert v. City of Richmond, 327 U.S. 416 (1946), the opinion emphasized the fact that the tax bore no relationship to the amount of business done and that such a municipal license tax could be duplicated in many cities, thus magnifying the burden. Moreover, a license tax affords local entities an opportunity to create protective barriers against interstate business. Robbins v. Shelby Taxing Dist., supra; Nippert v. City of Richmond, supra.

152112 Cal. 412, 44 Pac. 725 (1896).

153 Hansen v. Town of Antioch, 18 Cal. 2d 110, 114 P.2d 329 (1941); Town of St. Helena v. Butterworth, 198 Cal. 230, 244 Pac. 357 (1926). In the former case, the court justified the discrimination against itinerant merchants on the ground that they do not pay taxes which the merchants witll established places of business are required to pay. For a criticism of this reason, see text following note 139 supra.

154 American Bakeries Co. v. City of Opelika, 229 Ala. 388, 157 So. 206 (1934); National Linen Serv. Corp. v. City of Gainesville, 181 Ga. 397, 182 S.E. 610 (1936); City of Fairfield of Shallenberger, 135 Iowa 615, 113 N.W. 459 (1907); Jellico Grocery Co. v. City of Whitesburg, $286 \mathrm{Ky} .470$, 151 S.W.2d 35 (1941).

155 E.g., Landham v. City of La Grange, 163 Ga. 570, 136 S.E. 514 (1927).

156 Duffin v. Tucker, 113 Fla. 621, 153 So. 298 (1934); Farris v. Hall, 115 Fla. 433, 156 So. 114 (1934) (Florida cases holding solicitations followed by delivery could not be taxed on the ground that a segment of a business could not be made the subject of an occupation tax); Lynch v. City of Long Beach, 111 N.J.L. 148, 167 Atl. 664 (Sup. Ct. 1933); cf. City of North Wildwood v. Coney, 100 N.J.L. 38, 124 Atl. 515 (Sup. Ct. 1924) (New 
The courts slould not sustain an occupation license tax which imposes a burden on itinerant personnel greater than that imposed on established places of business within the taxing city solely on the ground that the classification is based on differences in the mode of doing business. Such a tax calls for a careful analysis of adverse effects on intercity commerce.

First, where there is no competing local merchant, a selective license tax upon itinerant merchants does not, of course, discriminate in favor of any competing local inerchant. But there may still be an adverse effect on intercity commerce. For example, in a metropolitan area it is probable that a firm in the wholesale bread business will have one bakery plant from which orders from retail grocers in various cities will be filled. If there is no competing local mercliant, all competitors in this market are treated alike. But by the same token, there is little political restraint on the taxing entity since whatever burden might ultimately be borne by the consumers in the taxing city is too diluted to lave much effect on them. ${ }^{157}$ The danger of this type of discriminatory tax is that the distribution of goods generally may be deterred to the extent that the demand for the goods are elastic and the tax in the taxing city causes a general increase in the price of goods everywhere. ${ }^{168}$ It would appear, lowever, that the validity of these selective taxes will be tested by the rationality of the classification, that is, the reasonableness of differentiating the particular business upon which the selective tax is imposed-an area where the courts would probably give utmost deference to legislative discretion.

Tle second situation is where either a general or a selective tax upon itinerant business in the city is higler than the tax upon the competing local merchants operating from establislied places of business within the

Jersey cases holding that cities do not have power to levy license tax where only a segment of a business conducted in the city); C. D. Kenny Co. v. Town of Brevard, 217 N.C. 269, 7 S.E.2d 542 (1940) (a license tax based on a flat fee per truck invalid as applied to solicitation in city followed by delivery by truck on the ground that the city does not have a power to $\operatorname{tax}$ that portion of the business carried on in another city); Great Atl. \& Pac. Tea Co. v. Village of Tippecanoe, 85 Ohio St. 120, 96 N.E. 1092 (1911); Shipley Baking Co. v. City of Hartshorne, 156 Okla. 74, 9 P.2d 754 (1932) (higher hicense tax on itinerant merchants held discriminatory as against nonresidents of the city).

157 But see Independent Warehouses v. Scheele, 331 U.S. 70 (1947), in which the majority sustained a municipal warehouse tax which apparently operated on a warehousethe only one in the taxing entity-which stored goods coming from outside the city and moving to points outside the state. For a criticism of this result, see Barrett, "Substance" vs. "Form" in the Application of the Commerce Clause to State Taxation, $101 \mathrm{U}$. PA. L. REv. 740,783 (1953).

158 The impact here on intercity commerce is only slightly different from a license tax imposed upon transportation of goods through the city. Such a tax operates as a toll with no local political restraint, and to the extent that the cost of transportation is increased, intercity commerce may be impeded. 
city. If the local merchants operate through itinerant personnel in addition to established places of business, they, too, would be subject to the higher tax. But if the local merchants do not so operate, this type of tax is clearly discriminatory against those operating from outside the city. The abuse which is possible in the smaller communities with this type of tax is apparent, for not only is there no political restraint but there are apt to be local pressures for the establishment of this trade barrier. ${ }^{169}$ That this danger exists is attested to by the number of cases in other states which have declared a tax on itinerant merchants invalid because the amount of tax was deemed prohibitory. ${ }^{160}$ Judicial control based on whether the amount of tax on the itinerant merchant is prohibitory is at best a crude method. At the same time, making the validity of the tax turn on whether the current competing business in the city also employs itinerant representatives injects temporal uncertainty as well as difficult questions of fact.

The real issue is whether a discriminatory tax based on differences in the mode of operation within the taxing city should be permitted. This issue, lowever, is further complicated by the fact that an itinerant taxpayer in the taxing city may be engaged entirely in itinerant business or may operate an establisleed place of business in another city with an itinerant representative in the taxing city. Although there are varying shades of differences in the mode of operation in the situations mentioned

159 See American Bakeries Co. v. City of Opelika, 229 Ala. 388, 157 So. 206 (1934), where the ordinance which originally discriminated on the basis of whether the bakery plant was located within or without the city-conceded by the parties to be invalid-was amended to levy a flat fee tax on itinerant dealers. The case is not clear as to whether the local bakery operated with itinerant personnel, but it illustrates that a minor change in the taxing provision might be sufficient to legally effect a discrimination against outside business.

In the City of Berkeley, a peddler or a solicitor must pay a semiannual tax of $\$ 45$. In contrast, a person selling the same kind of product from an established place of business is charged on the basis of average nuunber of employees. A person who conducts a business by himself is required to pay $\$ 30$ a year, and not until he hires eight persons will he be required to pay \$88. BERKEIEY, CAI. BUS. IIC. ORD. \$§ 5.1, 5.3 as amended (1964).

160 The cases are not consistent as to whether the reasonableness will be determined in terms of the class of taxpayers or of the particular taxpayer who is contesting the tax. Southern Linen Supply Co. v. City of Hazard, 286 Ky. 626, 151 S.W.2d 758 (1941) ( $\$ 400$ per year on laundry solicitation deemed invalid per se); Fetler v. City of Richmond, 346 Mo. 431, 142 S.W.2d 6 (1940) ( $\$ 5$ per day, $\$ 50$ per month and $\$ 100$ per year on bread peddling; the size of the city considered for earming potential); Hoyt Bros. Inc. v. City of Lincoln, 130 Neb. 79, 263 N.W. 898 (1936) (\$55 per month on peddlers; earnings of taxpayer considered); Gurland v. Town of Kearny, I28 N.J.L. 22, 24 A.2d 210 (Sup. Ct. 1942) ( $\$ 300$ per year on each vehicle used for ice cream peddling; the fact that the tax amounted to $30 \%$ of taxpayer's gross sales considered); Ex parte Davis, 72 Okla. Crim. 152, 114 P.2d 186 (1941) ( $\$ 5$ per day, $\$ 20$ per week, $\$ 35$ per month and $\$ 75$ per six months; that local merchants were not taxed was noted; taxpayer introduced no evidence to show he made less than the tax); Olan Mills, Inc. v. City of Sharon, $371 \mathrm{~Pa} .609,92$ A.2d 222 (1952) (\$200 per month deemed invalid per se). 
above, a discrimination on the face of the ordinance against itinerant business should not be permissible because of the probable adverse effect on intrastate commerce.

A third situation is where a selective tax does not discriminate against outside business because the very nature of the business requires the local concern to operate with itinerant personnel. For example, if a tax is levied on the business of pickup and delivery of linen supply, the tax operates equally upon the outside business as well as the local business. The danger, however, lies in the measure of the tax. For example, if the tax were measured by a flat fee, the intercity business may be bearing a heavier burden, as will be shown in the discussion of the next situation.

A fourth situation is where a general license tax, that is, a tax which is non-discriminatory on its face, is imposed upon all those conducting a business within the taxing city, including those operating solely with itinerant personnel. In this situation, a burden upon intercity commerce could arise only if the measure of the tax does not reflect the amount of business conducted in the city. For example, a flat fee may impose a greater burden upon the itinerant intercity business because that business may be subjected to the flat fee tax in each city in which it operates without regard to the amount of business conducted.101 The local business, not venturing outside the city, will be subjected to only one flat fee tax. The outside business operating through itinerant personnel will pay a flat fee only for that segment of its business which is being conducted in the taxing city while the local merchant pays the same flat fee for the entirety of its business. ${ }^{162}$

It is arguable that the decisions which have sustained a flat fee tax on itinerant business are inconsistent with the later cases which have struck down taxes measured in part by the number of vehicles. ${ }^{103}$ The rationale of these later cases was that the tax measure was arbitrary in that it bore no relation to the amount of business done in the taxing city.

161 See Nippert v. City of Richmond, 327 U.S. 416 (1946). In this respect, however, no distinction should be made between peddlers and solicitors, for the burden would be similar on both types of itinerants. See Barrett, supra note 157 at 782 .

102 See Duffin v. Tucker, 113 Fla. 621, 153 So. 298 (1939); City of North Wildwood v. Coney, 100 N.J.L. 38, 124 Atl. 515 (Sup. Ct. 1924).

It is no answer to point to the fact that, the filat fee may impose an unequal burden even among those doing busimess within the city because of their varying income. This type of discrimination is inevitable in a flat fee, but it is a discrimination which arises from the taxpayer's business judgment and skill. In contrast, the intercity operator can minimize the burden only by a decision to terminate his intercity activities.

163 City of Los Angeles v, Drake, 195 Cal. App., 2d 744, 16 Cal. Rptr. 103 (1961); City of Los Angeles v. Carson, 181 Cal. App. 2d 540, 5 Cal. Rptr. 356 -(1960); Security Truck Line v. City of Monterey, 117 Cal. App. 2d 441, 256 P.2d 366, 257 P.2d 755 (1953). For a discussion of the Security case, see text accompanying note 176 infra. 
(d) An Unapportioned Tax on Intercity Activities.-The United States Supreme Court has not been consistent as to when a tax must be apportioned. The Court has required that a property tax levied upon instrumentalities of commerce be apportioned if the instrumentalities are habitually used in more than one state. ${ }^{164} \mathrm{~A}$ tax on net income or measured by net income of an interstate business, where the taxpayer is not domiciled in the state, must be apportioned. ${ }^{165}$ The early cases indicated that a tax measured by gross receipts had to be apportioned if the activities giving rise to the gross receipts occurred in more than one state. ${ }^{166}$ The more recent cases indicate the Court's willingness to sustain a tax measured by unapportioned gross receipts derived from multi-state activities if the Court deems that the tax relates to substantial local activities of the taxpayer. ${ }^{167}$

Whether based on due process or on commerce clause grounds, the requirement for apportionment militates against multiple taxation on the

164 E.g., Central R.R. v. Pennsylvania, 370 U.S. 607 (1962); Standard Oil Co. v. Peck, 342 U.S. 382 (1952). Compare Braniff Airways, Inc. v. Nebraska State Bd. of Equalization, 347 U.S. 590 (1954), with Northwest Airlines v. Minnesota, 322 U.S. 292 (1944).

165 E.g., Butler Bros. v. McColgan, 315 U.S. 50I (1942); Flans Rees' Sons, Inc. v. North Carolina ex rel. Maxwell, 283 U.S. 123 (1931).

166 Gwin, White \& Prince, Inc. v. Henneford, 305 U.S. 434 (1939); J. D. Adams Mfg. Co. v. Storen, 304 U.S. 307 (1938) (these cases involved the producing states' attempts to tax the entire gross receipts). It should be noted that a tax measured by gross receipts, even when imposed upon a taxpayer whose activities have been confined to one state, has been invalidated when the activities are characterized as interstate commerce. Puget Sound Co. v. State Tax Comm'n, 302. U.S. 90 (1937).

107 The most recent case, General Motors Corp. v. Washington, 377 U.S. 436 (1964), involved a Washington privilege tax on wholesalers, which was measured by their sales, The taxpayer, which had neither offices for most divisions nor a manufacturing plant, promoted sales of cars and parts in Washington through resident district managers and service personnel; those persons were under the supervision of a zone manager in Oregon who made periodic trips into Washington. Washington orders were accepted or rejected outside the state, and cars were shipped from plants outside the state. Though there were differences in operation among the divisions, the above facts describe the essence of operation. The Court sustained an unapportioned tax measured by gross receipts from those goods delivered to Washington dealers. The majority commenced with the premise that a gross receipts tax should not impose a multiple burden on interstate commerce and that it inust be "fairly" apportioned, but the opimion does not disclose why the inclusion of unapportioned gross receipts in this case met the test of fair apportionment except to state that the taxpayer conducted substantial selling activities in the state. The majority dismissed the danger of inultiple taxation arising from the possibility of Oregon imposing a tax on the same gross receipts and from an already existing gross receipts tax on manufacturing imposed by another state; the majority stated that the taxpayer failed to sustain its burden of showing multiple taxation.

However, gross receipts arising from sales dissociated from activities in the state would still be immune. Norton Co. v. Department of Revenue, 340 U.S. 534 (1951). See also City of Chicago v. Willett Co., 344 U.S. 574 (1953), in which the Court sustained, on the "home port" doctrine, a tax on a transportation business measured by the size of the truck without requiring apportionment, even though the taxpayer was engaged in some interstate commerce with those trucks used as a measure of the tax. 
multi-state business. Thus, permitting an unapportioned gross receipts tax on the selling activity in one state as well as permitting taxation of the manufacturing activity in another state may appear to be inconsistent with the required apportioninent of net income, but the inconsistency is more apparent than real. ${ }^{168}$ If the marketing activities are subject to the gross receipts tax by the market state, the competing merchants, whether local or multi-state, face the same tax situation in terms of the burden on the marketing activity. It may be that the outside busmess is subject to a tax on manufacturing while the local merchant is not so taxed, but this type of discrimination appears inevitable in a federal system in which each state is permitted the maximum latitude in devising its own tax structure. It is probable that this type of discrimination can be avoided only by a uniform tax system among the states. What must be guarded against, however, is a multiple tax on the same activity of a multi-state business. In other words, where the selling activity spans two or more states, an unapportioned gross receipts tax by each of the states in which part of the selling activity occurs would impose an intolerable burden upon this multi-state business. The Supreme Court has thus far refused to deal with this problem.

The problem of multiple burdens arising from an unapportioned measure of tax has been variously handled by the California courts and in some respects they have gone further than the United States Supreme Court in requiring apportionment.

City of Los Angeles v. Belridge Oil Co. ${ }^{169}$ is an illuminating case in this regard. ${ }^{170}$ The taxpayer maintained its head office in the City of Los Angeles where the board of directors met and the principal officers performed their activities. Approximately seven percent of the full-time personnel worked at this office. The taxpayer had producing oil and gas wells in Kern County. The taxpayer's sales contracts were negotiated by officers who most of the time worked at the head office; about fifteen percent of the time required for negotiating sales was spent in Los Angeles, about fifteen percent in San Francisco in the purchasers' offices, while the remainder of the negotiations were handled by mail, telephone, and telegraph. The contracts were sigued in Los Angeles. The oil and gas were delivered to the purchasers at the well site. Under these circum-

168 Because the Court permits the apportionment of net income on a nonuniform basis, there can be multiple taxation to the extent that more than $100 \%$ of the net income is included in the measure of the tax by the states imposing a tax on a particular multi-state business.

16942 Cal. 2d 823, 271 P.2d 5 (1954), appeal dismissed, 348 U.S. 907 (1955); 48 Cal. 2d 320, 309 P.2d 417 (1957).

170 The facts are derived from the opinion of the district court of appeal. See 260 P.2d 217 (1953). 
stances, the issue arose as to whether the Los Angeles privilege tax on the business of selling, as measured by gross receipts, was applicable. In sustaining the applicability of the license tax to the taxpayer, the court held:

In the instant case we can find no objection, constitutional or otherwise, to the imposition of a business license tax on the privilege of engaging in selling activities within the city. Likewise there is no objection to basing the rate of such tax on the gross receipts attributable to such selling activities, even though various extraterritorial events contribute to such gross receipts. There is, however, one important limitation which should be pointed out and that is this: even though the city can tax the activity of selling it can only base the tax on such selling activities as are carried out within its territorial limits. ${ }^{171}$

The above opinion seems to indicate that the gross receipts arising from substantial selling activities in the taxing city may be included in the measure of the tax. The district court of appeals on remand of the case so construed the opinion, permitting the city to include all gross receipts from sales having contact with the Los Angeles office in the measure of the tax despite the stipulation of the parties that each dollar of gross receipts was attributable to selling activities within and without the city. ${ }^{172}$ The California Supreme Court, rejecting the district court's formulation, sustained the trial court which had apportioned the gross receipts. ${ }^{173}$ In short, the court, although not requiring an apportionment of the gross receipts between production and sales, does appear to require

17142 Cal. $2 \mathrm{~d}$ at 831,271 P.2d at 10.

172302 P.2d 854 (1956). Whether the parties thought that each dollar of gross receipts involved multi-city sales activity because each contract involved negotiations in San Francisco, Los Angeles, and through the mail or because delivery was considered to be sales activity is not clear. The parties stipulated at the second trial that delivery was part of the selling activities. 302 P.2d at 858. It appears that the trial court required apportionment of the gross receipts on the basis of "payroll, value and situs of tangible property, general expenses," and other factors; the parties arrived at an apportionment of $20 \%$ of the gross receipts to Los Angeles.

173 The court does not make clear the precise ground for its opinion. At one point the court appears to be construing the tax ordinance when it states that the gross receipts from extraterritorial selling activities cannot be included in the measure of the tax because the license tax necessarily taxes only the privilege of engaging in business within the city. $42 \mathrm{Cal} .2 \mathrm{~d}$ at 832,271 P.2d at 11 . On the other hand, the court states that there would be an "unreasonable discrimination and a demal of equal protection" if extraterritorial gross receipts were included in the measure of the tax. Id. at 832, 271 P.2d at 11 . And the court expressly rejects the city's contention that "due process and equal protection do not compel an apportionment of receipts attributable to the business carried on within the city." $48 \mathrm{Cal} .2 \mathrm{~d}$ at 320,309 P.2d at 419 . It is evident from its first opinion that the supreme court would not have required an apportionment because of delivery outside the city, for the court states: "In the case at bar it is true that some of these gross receipts are attributable to extraterritorial elements such as the production and delivery of the goods. However, there is no constitutional objection to resorting to extraterritorial elements in determining the rate of tax." $42 \mathrm{Cal} .2 \mathrm{~d}$ at 831,271 P.2d at 10. 
apportionment where the sales are only partly attributable to activities conducted in the taxing city.

The requirement of apportionment was not an innovation in the Belridge case, however. In Ferran v. City of Palo Alto, ${ }^{174}$ the city imposed a license tax on the business of laundering and taking orders for laundering. The tax was measured by the total number of employees even though most of the taxpayer's employees were located at the laundry plant outside the city. The court invalidated the tax on the grounds that it amounted to a denial of equal protection and resulted in an extraterritorial application of the tax..$^{175}$

More recently, in Security Truck Line v. City of Monterey, ${ }^{170}$ a license tax upon the business of transportation measured by the unladen weight of the vehicle has been held to violate "constitutional limitations," as applied to a taxpayer who hauled goods into the taxing city from outside points. The court held that the measure of the tax was arbitrary and capricious since it bore no relation to the business done in the city; a person using one truck would lavie his tax measured by the weight of that truck regardless of the number of deliveries made in the city but a person making the same number of deliveries in different vehicles would be required to pay a tax on each vehicle. ${ }^{177}$

The court in the Security Truck Line case did not discuss whether the tax would have been valid had it been measured by the tonnage of freight carried into the city. ${ }^{178}$ It is submitted that even that measure would be invalid if a tax is required to be measured by the events occurring in the taxing city, as seems to be required in the Security Truck Line case and in the Belridge Oil Co. case. The transportation of goods involves pickups as well as deliveries and transportation between

17450 Cal, App. 2d 374, 122 P,2d 965 (1942).

175 Several cases in other states have invalidated a tax on the ground that the measure of tax included activities conducted outside the city. E.g., City Council of Augusta v. Southern Groceries Stores Inc, 189 Ga. 618, 7 S.E.2d 181 (1940); Sunflower Tip Top Dairies Co. v. City of Russell, 188 Kan. 238, 362 P.2d 76 (1961).

176117 Cal. App. 2d 441, 256 P.2d 366, 257 P.2d 755 (1953).

177 Cases which arrived at the same result under similar measure of taxes are City of Los Angeles v. Drake, 195 Cal. App. 2d 744, 16 Cal. Rptr. 103 (1961); City of Los Angeles v. Carson, 181. Cal. App. 2d 540, 5 Cal. Rptr. 356, (1960).

178 California Fireproof Storage Co. v. City of Santa Momica, 206 Cal. 714, 275 Pac. 948 (1929), sustained a tax on transportation, measured by tonnage of freight transported, levied upon a taxpayer who made pickups and deliveries in the city but engaged in no intracity transportation. The taxpayer argued that the city ;had no jurisdiction to tax and did not urge the necessity of apportionment. City of Los Angeles v. Tannahill, $105 \mathrm{Cal}$. App. 2d 541, 233 P.2d 671 (1951), sustained a tax measured by unladen weight of the taxpayer's truck. The taxpayer made deliveries into the taxing city but did no intracity business. The taxpayer again did not argue that the measure of the tax was bad because of his intercity business. 
points. The tonnage measure would attribute all of the transportation business to the taxing city. ${ }^{179}$

In another context, the court has taken a more stringent attitude. Where a taxpayer was engaged in the transportation business between two points but merely passed through the city, the court refused to allow the city to impose a tax on the ground that the taxpayer was not engaged in any business in the city. ${ }^{180}$

\section{CONCLUSTON}

The purpose of this article was to examine the constitutional and statutory authority of a county and a city to levy an occupation tax and to explore the judicial limitations upon such authority. The chartered cities, by virtue of the constitutional grant to make all laws in respect to "municipal affairs," need no statutory authority. The general law cities have been provided the power by the state legislature. The counties without a cliarter have been delegated the authority to impose an occupation tax only in a very limited area. The chartered counties probably do not have any direct constitutional authority but the Supreme Court of Califorma has so confused the matter by referring to the "municipal affairs" of a county ${ }^{181}$ that the answer cannot be given with certainty.

There was a period when it appeared that a state licensee was immune from the local occupation tax, but the court has retreated to the earher law whicl did not deem a local revenue measure to be in conflict with state regulatory provisions. There remains, however, the problem whether the Uniform Local Sales and Use Tax Law precludes other occupation taxes on a retailer.

Insofar as burdens upon intercity commerce are concerned, the California courts have evolved a flexible doctrine to regulate municipal hicense taxes but the courts have not always been consistent. Reconciliation of the interests of a city in terms of its need for revenue and efficient tax administration and the public interest in free flow of commerce among the cities is not easy. If the cities were required to adopt uniform taxes upon intercity business and local competing business measured by the amount of business done, the burden upon intercity business would be alleviated to a great extent. However, the cost of administration by the city and the cost of compliance by the taxpayer will increase under such a

$179 \mathrm{An}$ apportionment based upon average number of employees working in the taxing city was sustained in Arnke v. City of Berkeley, 185 Cal. App. 2d 842, 8 Cal. Rptr. 645 (1960).

180 Matter of Smith, 33 Cal. App. 161, 164 Pac. 618 (1917): But see Central Greyhound Lines, Inc. v. Mealey, 334 U.S. 653 (1948), for dictum which suggests the validity of a tax on apportioned gross receipts based on mileage as applied to an interstate carrier.

181 See note 42 supra. 
system. Even under such a system, the taxpayer might be given an option to pay a flat fee for a short period or a tax measured by the business done, ${ }^{182}$ but unless the flat fee schedule can be constructed to roughly equate the schedule of the tax measured by the business done, the option could be illusory.

The League of California Cities, aware of these problems, has suggested an ordinance with these optional features for those without fixed places of business in the city. ${ }^{183}$ The suggested ordinance appears to adopt the gross receipts measure for most businesses althougl provision is made for a flat fee tax. The suggested ordinance generally is good, but there are important matters left unsettled. First, there is no provision indicating where or how the gross receipts should be allocated where the gross receipts arise from activities conducted in several cities, such as sales from solicitation. Second, the cities are left to make the determinations as to which businesses slould be taxed on the basis of gross receipts or by a flat fee. Third, it is merely a suggestion and whether the cities will ever adopt the suggested ordinance to attain a uniform business tax remains extremely problematical.

Perhaps the time has come for the legislature to investigate this problem with a view to requiring a uniform busmess tax provision. In the light of the impact upon intercity business, the chartered cities would no longer be able to assert "muinicipal affair" to thwart statewide uniformity. ${ }^{184}$

182 The City of Berkeley seeks, to alleviate somewhat the hardship upon those who for less than a year conduct business within the city without an established place of business within the city. Such persons may acquire a bicense for a semi-annual period at a flat fee of $\$ 15$, which is the minimum tax. BERKELEX, CAX. BUS. Lic. ORD. $\$ \S 3.3,5.8$ as amended (1964). However, prior to the expiration of the period for which a license is obtained, the taxpayer must compute his tax upon the basis of average number of employees employed within the city for that period. BERRELEX, CaI. Bus. LIC. ORD. \$ 3.3. This scbeme, however, has several limitations. If the taxpayer enters the city to conduct business for several days in each semi-annual period, he will be required to pay the same amount as those with established places of business. Only if the taxpayer restricts his business witbin the city to one semi-annual period will he be able to pay one-half the amount of the tax imposed upon those; conducting business at established places of business within the city. Berkedey, Car. Bus. Lic. ORD. $\$ \$ 1.2-5,1.2-6,3.3$ (1963). This scheme, sustained in Arnke v. City of Berkeley, 185 Cal. App. 2d 842, 8 Cal. Rptr. 645 (1960), does apportion the taxpayer's business. It is, however, discriminatory against him since the burden is the same whether he has conducted business witlin the city three days or a whole year. Moreover, the graduated tax diminishes upon each increment of additional employees so that he must pay the maximum rate for conducting the minimum business.

183 League of CaITfornta Cities, Business License TAXEs 34 (1957).

184 Cf. Professional Fire Fighters, Inc. v. City of Los Angeles, 60 Cal. 2d 276, 384 P.2d 158, 32 Cal. Rptr. 830 (1963); Pacific Tel. \& Tel. Co. v. City and County of San Francisco, 51 Cal. 2d 766, 336 P.2d 514 (1959). 